\title{
Particle bombardment and the genetic enhancement of crops: myths and realities
}

Fredy Altpeter ${ }^{1}$, Niranjan Baisakh ${ }^{2}$, Roger Beachy ${ }^{3}$, Ralph Bock ${ }^{4,5}$, Teresa Capell ${ }^{6}$, Paul Christou $^{6, *}$, Henry Daniell ${ }^{7}$, Karabi Datta ${ }^{2}$, Swapan Datta ${ }^{2}$, Philip J. Dix ${ }^{8}$, Claude Fauquet $^{10}$, Ning Huang ${ }^{10}$, Ajay Kohli ${ }^{11}$, Hans Mooibroek ${ }^{12}$, Liz Nicholson ${ }^{13}$, Thi Thanh Nguyen $^{14}$, Gregory Nugent ${ }^{14}$, Krit Raemakers ${ }^{15}$, Andrea Romano ${ }^{16}$, David A. Somers ${ }^{17}$, Eva Stoger ${ }^{18}$, Nigel Taylor ${ }^{9}$ and Richard Visser ${ }^{15}$

${ }^{1}$ Laboratory of Molecular Plant Physiology, Agronomy Department, University of Florida - IFAS, 2191 McCarty Hall, P.O. Box 110300, Gainesville, FL 32611-0300, USA; ${ }^{2}$ Division of Plant Breeding, Genetics, and Biochemistry, International Rice Research Institute, DAPO Box 7777, Metro Manila, The Philippines; ${ }^{3}$ Danforth Plant Science Center, 975 North Warson Road, St. Louis, USA; ${ }^{4}$ Westfälische WilhelmsUniversität Münster, Institut für Biochemie und Biotechnologie der Pflanzen, Hindenburgplatz 55, D-48143 Münster, Germany; ${ }^{5}$ Max-Planck-Institut für Molekulare Pflanzenphysiologie, Am Mühlenberg 1, D-14476 Golm, Germany; ${ }^{6}$ Department de Produccio Vegetal i Ciencia Forestal, Universitat de Lleida, Av. Alcalde Rovira Roure, 191 E-25198 Lleida, Spain; ${ }^{7}$ Department of Molecular Biology and Microbiology, University of Central Florida, Orlando, FL 32816-2364, USA $;^{8}$ Institute of Bioengineering and Agroecology, Department of Biology, National University of Ireland Maynooth, Maynooth, Co. Kildare, Ireland; ${ }^{9}$ International Laboratory for Tropical Agricultural Biotechnology (ILTAB), Danforth Plant Science Center, 975 North Warson Road, St. Louis, USA; ${ }^{10}$ Ventria Bioscience, 4110 North Freeway, Sacramento, CA 95834, USA; ${ }^{11}$ Institute of Research on Environment and Sustainability (IRES), Devonshire Building, School of Biology, University of Newcastle upon Tyne, Newcastle upon Tyne NE1 7RU, UK, ${ }^{12}$ Agrotechnology and Food Innovations B.V., Department of Bioconversion, Wageningen University and Research Centre, Bornsesteeg 59, 6708 PD Wageningen, The Netherlands; ${ }^{13}$ John Innes Centre, Norwich Research Park, Norwich NR4 7UH, UK; ${ }^{14}$ Department of Primary Industries, Primary Industries Research Victoria, Plant Biotechnology Centre, La Trobe University, Bundoora 3086, Victoria, Australia; ${ }^{15}$ Laboratory of Plant Breeding, Wageningen University and Research Centre, P.O.B. 386, 6700AJ Wageningen, The Netherlands; ${ }^{16}$ Research Institute GROW, Department of Obstetrics and Gynaecology, University Hospital of Maastricht, P. Debyelaan 25, 6202 AZ, Maastricht, The Netherlands; ${ }^{17}$ Department of Agronomy and Plant Genetics, University of Minnesota, St. Paul, Minnesota, USA; ${ }^{18}$ Institute for Molecular Biotechnology, Biology VII, RWTH Aachen, Worringerweg 1, 52074 Aachen, Germany;*Author for correspondence (e-mail: paul.christou@icrea.es)

Received 30 November 2004; accepted in revised form 22 December 2004

Authors are listed in strict alphabetical order

Key words: Crops, Genetic engineering, Particle bombardment, Transformation, Transgene expression, Transgene structure, Transgenic plants

\section{Abstract}

DNA transfer by particle bombardment makes use of physical processes to achieve the transformation of crop plants. There is no dependence on bacteria, so the limitations inherent in organisms such as Agrobacterium tumefaciens do not apply. The absence of biological constraints, at least until DNA has entered the plant cell, means that particle bombardment is a versatile and effective transformation method, not 
limited by cell type, species or genotype. There are no intrinsic vector requirements so transgenes of any size and arrangement can be introduced, and multiple gene cotransformation is straightforward. The perceived disadvantages of particle bombardment compared to Agrobacterium-mediated transformation, i.e. the tendency to generate large transgene arrays containing rearranged and broken transgene copies, are not borne out by the recent detailed structural analysis of transgene loci produced by each of the methods. There is also little evidence for major differences in the levels of transgene instability and silencing when these transformation methods are compared in agriculturally important cereals and legumes, and other non-model systems. Indeed, a major advantage of particle bombardment is that the delivered DNA can be manipulated to influence the quality and structure of the resultant transgene loci. This has been demonstrated in recently reported strategies that favor the recovery of transgenic plants containing intact, singlecopy integration events, and demonstrating high-level transgene expression. At the current time, particle bombardment is the most efficient way to achieve plastid transformation in plants and is the only method so far used to achieve mitochondrial transformation. In this review, we discuss recent data highlighting the positive impact of particle bombardment on the genetic transformation of plants, focusing on the fate of exogenous DNA, its organization and its expression in the plant cell. We also discuss some of the most important applications of this technology including the deployment of transgenic plants under field conditions.

\section{Introduction}

Direct transfer methods for plant transformation rely entirely on physical or chemical principles to deliver DNA into the plant cell. Several different direct DNA transfer methods have been described, including particle bombardment (Klein et al. 1987; Christou et al. 1992), microinjection (Crossway et al. 1986), transformation of protoplasts mediated by polyethylene glycol or calcium phosphate (Negrutiu et al. 1987; Datta et al. 1990) electroporation (Shillito et al. 1985; Fromm et al. 1986) and transformation using silicon carbide whiskers (Frame et al. 1994). Among these methods, particle bombardment has been used the most widely for generating commercial transgenic crops, and the delivery of transgenes into embryonic tissues by particle bombardment remains the principle direct DNA transfer technique in plant biotechnology (James 2003).

Several investigators have recently suggested that particle bombardment will inevitably be supplanted by transformation methods using the soil bacterium Agrobacterium tumefaciens and its relatives, at least for the production of commercial genetically enhanced crops (Gelvin 2003; Tzfira and Citovsky 2003; Valentine 2003). The subject of genetically enhanced crops has ignited an intense, polarized and often hostile debate in many countries, with emotive issues taking the lead over scientific rigor and common sense. Agrobacterium spp., as natural conduits for gene transfer between bacteria and plants, are regarded by some as more 'natural' than direct transfer methods, and therefore more acceptable (Verhoog 2003). There is also a widely-held belief that Agrobacterium-mediated transformation is more precise, more controllable and therefore 'cleaner' than particle bombardment, but this axiom does not stand up to close scrutiny (especially in nonmodel plant systems). There have been many reports of vector backbone co-transfer by A. tumefaciens (e.g. see Ramanathan and Veluthambi 1995; van der Graaf et al. 1996; Kononov et al. 1997; Wenck et al. 1997; McCormac et al. 2001; Popelka and Altpeter 2003a) and it is clear, in the light of recent innovations, that particle bombardment allows much more precise control over transgene structure (Altpeter et al. 2000, 2004a; Fu et al. 2000; O'Kennedy et al. 2001; Smith et al. 2001; Twyman et al. 2002; Datta et al. 2003; Kim et al. 2003; Popelka et al. 2003; Romano et al. 2003a).

In this article, we present recent data from the authors' laboratories, which clearly demonstrate the suitability of particle bombardment for the precision engineering of a variety of plants, producing genetically enhanced varieties of crops 
(not just model plants such as Arabidopsis thaliana and tobacco) with stable and high level transgene expression (Taylor and Fauquet 2002). We discuss the versatility of particle bombardment as a transformation strategy and highlight recent advances showing how it is being applied to generate transgenic plants with a variety of enhanced and improved characteristics. Searching the Web of Science literature database for citations of particle bombardment in plants reveals 149 hits between 1987 and 1995, nearly 500 hits between 1995 and 2002, and nearly 200 hits from 2002 to the time of writing (November 2004).

\section{Particle bombardment facilitates a wide range of transformation strategies}

Genetic transformation occurs in two stages: DNA transfer into the cell followed by DNA integration into the genome. The integration stage is much less efficient than the DNA transfer stage, with the result that only a small proportion of the cells that initially receive DNA actually become stably transformed. In the remaining cells the DNA enters the cell and may be expressed for a short time (transient expression), but it is never integrated and is eventually degraded by nucleases. Transient expression occurs almost immediately after gene transfer, it does not require the regeneration of whole plants, and it occurs at a much higher frequency than stable integration. Therefore, transient expression can be used as a rapid assay to evaluate the efficiency of direct DNA transfer and to verify the function of expression constructs. Indeed, transient expression following particle bombardment with a reporter gene such as gus A or $g f p$ is used routinely to compare different expression constructs and identify those with the most appropriate activity. Where the aim is to extract recombinant proteins from transgenic plants, transient expression following particle bombardment may also be used to produce small amounts of protein rapidly for testing (Twyman et al. 2003).

Although particle bombardment can be used for transient expression studies, most publications and patents that cite the method concentrate on its potential for stable transformation, which is discussed in more detail below. In this context, the technique also demonstrates considerable versatility, since in addition to nuclear transformation it permits the transformation of plastids, a process that cannot be achieved with Agrobacterium spp. because the T-DNA complex is targeted to the nucleus. Furthermore, particle bombardment is thus far the only technique that can be used for mitochondrial transformation (Johnston et al. 1988), although this has yet to be achieved in higher plants.

Particle bombardment is also useful in transformation strategies involving plant viruses. Hoffman et al. (2001) have used particle bombardment for the mechanical transmission of poleroviruses, and particle bombardment is routinely employed for the inoculation of whole plants and leaf tissues with viruses that are difficult to introduce via conventional mechanical infection. The Biolistic and Helios systems can be used to circumvent the need to maintain virifilous populations of insect vectors, allowing direct introduction of infectious viral nucleic acids into a range of plant species (Briddon et al. 1998; Garrido-Ramirez et al. 2000; Chakraborty et al. 2003). An attractive feature of such systems is the flexibility by which co-infections can be achieved with different viral species and genomic components, generating a powerful tool for investigating mechanisms of pathogenicity and host resistance. In a recent report, particle bombardment was utilized both to produce transgenic cassava plants and to challenge them by simultaneous inoculation with two species of geminiviruses (Chellappan et al. 2005). Particle bombardment also has an important role to play in extending virus-induced gene silencing (VIGS) into economically important crop plants (Fofana et al. 2005).

\section{Particle bombardment has no biological constraints or host limitations}

One of the major advantages of particle bombardment is that it does not rely on the biological limitations of any single group of microorganisms. Consequently, the technique facilitated major advances in the transformation of several broad categories of plant species in the early 1990s, including the cereals (which were almost entirely intractable to Agrobacterium-mediated transformation until about 1997). Even today, 
Agrobacterium-mediated transformation of cereals, legumes and other species outside the classical host range - i.e. A. thaliana and many solanaceous plants - is generally only suitable for a limited range of genotypes. Particle bombardment overcomes these boundaries by exploiting physical principles to introduce the DNA into the plant cell, and then relying on factors that are common to all plants (i.e. DNA repair mechanisms) to enable stable transgene integration. Furthermore, particle bombardment protocols are now also available for filamentous fungi (Hazell et al. 2000; Harrier and Millam 2001), edible mushrooms (Sunagawa and Magae 2002) and even human cell lines (Zhang et al. 2002). For stable transformation and the recovery of transgenic plants, particle bombardment is restricted only by the requirement to deliver DNA into regenerable cells. By removing almost all the incidental biological constraints that limit other transformation methods, particle bombardment has facilitated the transformation of some of the most recalcitrant plant species.

As examples, we consider the transformation of rice and wheat, which have a large number of diverse cultivars. A genotype-independent method for rice transformation was originally reported by Christou et al. (1991) and has been widely used throughout the world. Researches at the International Rice Research Institute, The Philippines, have used particle bombardment successfully to transform over 20 different cultivars adapted to different eco-geographic conditions. These cultivars have been transformed with a range of agronomically important genes, confirming the genotype-independence of the transformation method (Table 1). Similarly, a less genotype-dependent method for wheat transformation by particle bombardment was reported by Altpeter et al. (1996a) and has been successfully used to transform 10 different wheat cultivars (Altpeter et al. 1996b; Varshney and Altpeter 2001). Inevitably, for most species there are varietal differences in the frequency with which transformed plants can be recovered after bombardment, since this depends on the efficiency with which adventitious shoots can be initiated on the explants. However, the method remains extremely versatile, generating transformants with relative ease for a wide range of cultivars in a wide range of species.

\section{Diverse cell types can be targeted efficiently for foreign DNA delivery}

Particle bombardment does not depend on any particular cell type as long as the DNA can be introduced into the cell without killing it. The production of transgenic plants from transformed cells depends only on the ability of such cells to exhibit totipotency under the culture conditions employed. In this context, particle bombardment is superior to other transformation methods because both single cells and organized tissues can be used as transformation targets, and conditions can be chosen to target superficial cells or cells residing in deeper layers in organized tissues, allowing the transformation of cell types that have traditionally been difficult to reach, such as dividing cells in the apical meristem.

A wide variety of cell and tissue explants have been utilized for particle bombardment, although as a general guide such explants should contain a large proportion of healthy and easily regenerable cells, preferably enriched with cells approaching nuclear division. Examples include embryos excised from seeds, shoot apices, excised discs from young leaves, callus tissue, microspores and immature pollen grains. In rice, the range of suitable tissues includes immature embryos (7-8 days after anthesis), embryogenic callus derived from either immature embryos or mature seeds, and suspension culture cells (Datta et al. 1998, 2001; Tu et al. 1998a, b; Baisakh et al. 2001). Transient expression has even been achieved using the intact immature seed endosperm following bombardment with a vector carrying the gus A reporter gene (Grosset et al. 1997; Clarke and Appels 1998). Onion embryogenic callus and mature embryos, and carrot hypocotyls have likewise been transiently transformed after delivering constructs containing $g f p$ or $g u s \mathrm{~A}$. For potato transformation, even non-embryogenic tissues (i.e. nodes, leaves and microtubers) have been shown to be suitable targets for both transient expression and stable transformation by particle bombardment in different cultivars (Romano et al. 2001, 2003b; Romano et al. 2005). This indicates that both undifferentiated cells and well-differentiated, organized tissues are amenable to this method of transformation. It should be noted, however, that such explants are not necessarily equally efficient in their response. Transformation efficiency also 


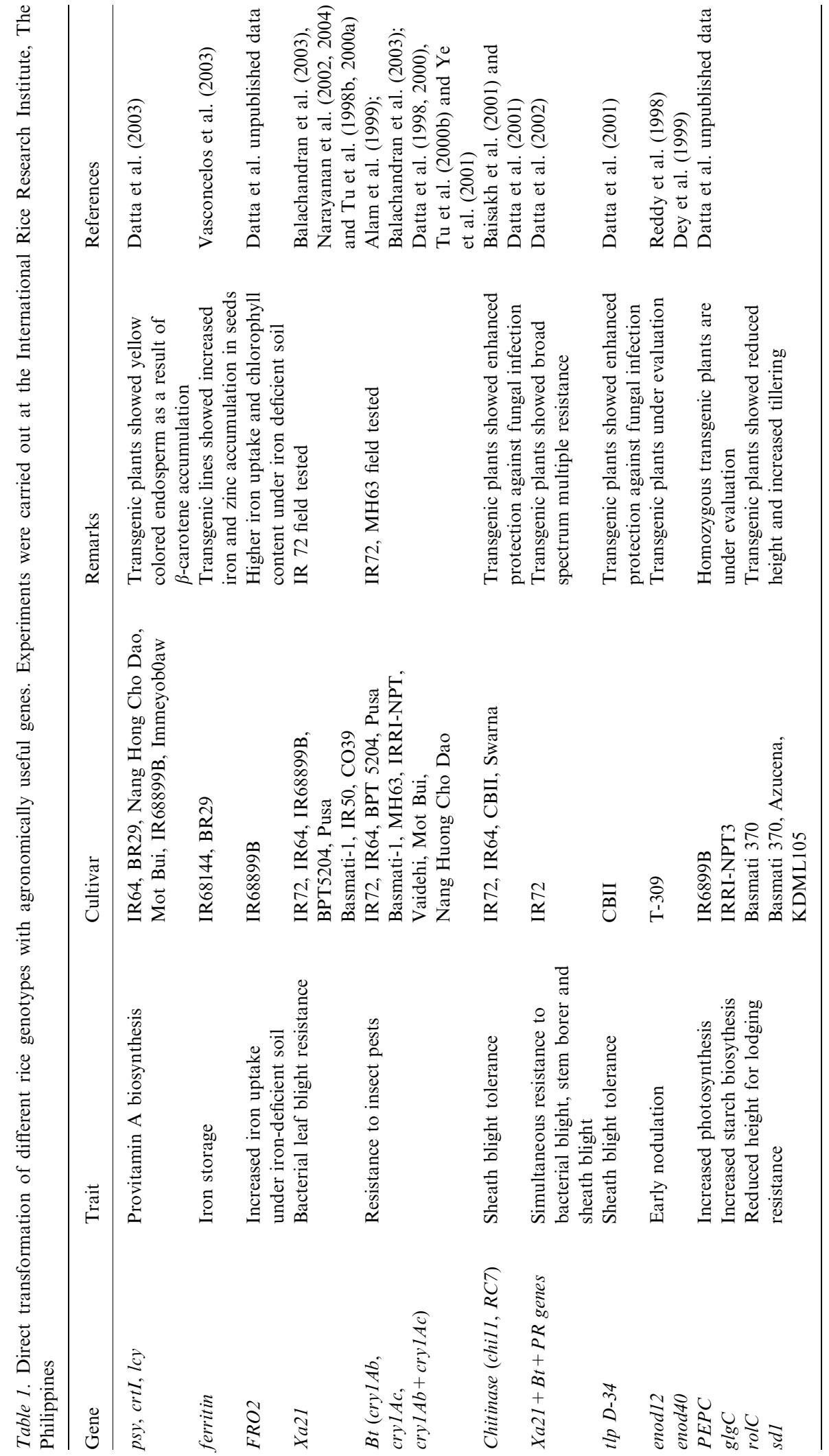


depends upon the regeneration capacity and the efficiency of selection, which in turn depends upon how different explants are handled. In most crops, selection is based on the use of antibiotics or herbicides, but chemical selection is not always necessary. In cassava, the luc gene was used to select plants containing an antisense gbssI transgene, which was expressed stably after 4 years. In wheat (Permingat et al. 2003) and rye (Popelka et al. 2003) embryogenic tissues were bombarded with only the primary transgene of interest, and regenerated plants were screened by PCR for the integrated transgene (present in $2 \%$ and $1.6 \%$ of the plants, respectively). The efficiency of particle bombardment can thus be high enough to dispense with marker genes all together.

The ability to transform diverse cell types by particle bombardment facilitates a broad range of applications that are difficult or impossible to achieve by other transformation methods. This is critical when the rapid analysis of large numbers of constructs in a specific tissue or cell type is required. The analysis of endosperm-specific promoters is an example of such a challenge. Transient expression studies using callus tissue, for example, provide no useful information about construct activity in the endosperm. On the other hand, the production of mature seeds from transgenic plants for promoter analysis in the endosperm is laborious and time-consuming. Furthermore, the expression profiles for each construct in transgenic plants can be misleading if the numbers of transgenic plants subjected to analysis are limited and position effects are significant. Hwang et al. (2001) used particle bombardment to transform immature rice endosperm 7-9 days after pollination. Transient expression was then used to evaluate endosperm-specific promoter activity and the effect of transcriptional activators (Hwang et al. 2001, 2002; Yang et al. 2001). The conclusions from these studies were later confirmed using transgenic plants. Extremely high levels of recombinant protein expression $(30-50 \%$ total soluble protein or $0.5-1 \%$ rice endosperm mass) were achieved in these experiments (Yang et al. 2001; Huang et al. 2002; Nandi et al. 2002; Yang and Huang unpublished data).

The lack of cell type dependence also allows particle bombardment to be used in the study of subcellular trafficking and storage protein deposition. This is another example of how transient expression can be used to provide data rapidly and inexpensively without the need to regenerate transgenic plants. Drakakaki et al. (2000) studied bombarded tobacco and rice callus and leaf material by electron microscopy to investigate in detail the deposition of recombinant proteins within the cells of these tissues. The same subcellular localization was later confirmed in the leaves of transgenic plants showing that the results obtained from transient expression assays could be extrapolated to transgenic plants. This strategy is feasible in all target tissues where a sufficient proportion of cells can be transiently transformed by bombardment, and has been demonstrated in species and tissues that are not amenable to agroinfiltration (transient transformation by vacuum infiltration with $A$. tumefaciens - a technique that can only be applied in leaves and other tissues with large spaces between cells).

\section{Vectors are not required for particle bombardment}

The exogenous DNA used in transformation experiments typically comprises a plant expression cassette inserted in a vector based on a high-copynumber bacterial cloning plasmid. Neither of these components is required for DNA transfer, and only the expression cassette is required for transgene expression. The vector backbone is therefore superfluous. The vector backbone typically includes a bacterial origin of replication and selectable marker, allowing the expression cassette to be cloned in Escherichia coli. The expression cassette typically comprises a promoter, open reading frame and polyadenylation site that are functional in plant cells, although other components may be present, such as a protein targeting signal. Once this plasmid has been isolated from the bacterial culture, it is purified and used directly as a substrate for transformation.

In Agrobacterium-mediated transformation, the transgene must be placed between T-DNA repeats, and further sequences such as overdrive and transfer enhancer may be required for efficient DNA delivery. There are no such biological constraints in particle bombardment and no vector DNA sequences are required for delivery. During Agrobacterium-mediated transformation, the T-DNA is naturally excised from the vector during the transformation process. This frequently, 
although not always, prevents the integration of vector backbone sequence into the plant genome (Fang et al. 2002; Popelka and Altpeter 2003a), necessitating time-consuming sequence analysis of transgene insertion sites following Agrobacteriummediated gene transfer.

In contrast, particle bombardment involves no such processing. Cloning vectors are used in particle bombardment for convenience rather than necessity. Consequently, Fu et al. (2000) devised a clean DNA strategy in which all vector sequences were removed prior to particle loading. A standard plasmid vector was used to clone the plant expression cassette and transgene of interest in bacteria, and then the cassette was excised from the plasmid and purified by agarose gel electrophoresis. This minimal, linear cassette was then used to coat the metal particles and carry out transformation. The results were interesting because, as well as proving that transformation and subsequent transgene expression were possible using minimal cassettes, the resulting transgenic plants showed much simpler integration patterns and lower transgene copy numbers than plants transformed with equivalent constructs in their source plasmids. These results have been confirmed in subsequent studies with agronomically useful genes and multiple cassettes, as discussed in the next section (Breitler et al. 2002; Loc et al. 2002; Romano et al. 2003a; Romano et al. 2005).

\section{Particle bombardment facilitates simultaneous multiple gene transformation}

Cotransformation is the simultaneous transformation of a plant cell with two or more transgenes. Multiple gene transfer to plants is necessary for sophisticated genetic manipulation strategies, such as the stacking of transgenes specifying different agronomic traits, the expression of different polypeptide subunits making up a multimeric protein, the introduction of several enzymes acting sequentially in a metabolic pathway or the expression of a target protein and one or more enzymes required for specific types of post-translational modification. Although this can be achieved by single gene transformation followed by the crossing of plant lines carrying different transgenes, it is much quicker and more straightforward to introduce all the necessary genes simultaneously. Furthermore, for some agronomically important crops like potato and cassava, the high level of heterozygosity in the species makes crossing approaches difficult and time consuming. Particle bombardment is the most convenient method for multiple gene transfer to plants since DNA mixtures comprising any number of different transformation constructs can be used, with no need for complex cloning strategies, multiple Agrobacterium strains or sequential crossing. Many studies describe successful integration of two or three different transgenes, in addition to the selectable marker, into plants by particle bombardment, and the maximum reported to date is 13 (Chen et al. 1998).

$\mathrm{Wu}$ et al. (2002) examined the co-transformation of rice with nine transgenes via particle bombardment and documented the levels of transgene expression. They found that nonselected transgenes were present along with the selectable marker in about $70 \%$ of the plants, and that $56 \%$ carried seven or more genes. This was much higher than expected given the independent integration frequencies, agreeing with a model proposing that the integration of one gene into a specific locus in the rice genome could mediate the insertion of other genes into the same locus (Kohli et al. 1998). This phenomenon is important when large numbers of genes are considered, since a much larger transgenic population would be required if each integration event were independent. $\mathrm{Wu}$ et al. (2002) also found that all the nine transgenes were expressed, and that the expression of one gene was independent of each other. These findings are extremely useful in designing multiple plasmid transformation experiments such as those required for plant metabolic engineering.

Gene transfer by particle bombardment has also been used simultaneously to introduce three coat protein genes from the same virus to generate rice plants with pyramidal resistance against a single pathogen (Sivamani et al. 1999). Similarly, Maqbool et al. (2001) have shown how the same transformation strategy can provide pyramidal insect resistance in rice. Datta et al. (2003) have succeeded in the development of Golden indica rice lines containing four genes, i.e. those required to extend the existing carotenoid metabolic pathway (psy, crtI and lcy) in addition to the selectable marker gene, either phosphomannose isomerase 
(pmi) or hygromycin phosphotransferase (hpt). All the genes in the metabolic pathway were shown to function coordinately to produce $\beta$-carotene in the endosperm, revealed by the yellow color of the polished rice seed. Capell and colleagues have also used particle bombardment to engineer a complex metabolic pathway, and have created a diverse range of rice germplasm with various genes in the polyamine biosynthetic pathway either over-expressed or suppressed through antisense mechanisms (Capell et al. 1998, 2000; Bassie et al. 2000a, b; Noury et al. 2000; Lepri et al. 2001; 2002; Thu-Hang et al. 2002; Trung-Nghia et al. 2003). Most recently, they have used the data from these numerous lines to synthesize a uniform model of polyamine regulation in plants, based on the simultaneous measurement of endogenous and heterologous gene expression, enzyme activities and polyamine levels (Capell et al. 2004). Huang and colleagues (Wu et al. 2002; Huang 2004; Huang unpublished data) engineered the phenylpropanoid pathway to produce plant lignans in rice endosperm. Long-term studies have shown that plant lignans may prevent the major hormone-dependant cancers, colon cancer and coronary heart disease. To elevate plant lignans in transgenic rice endosperm, the rice glutelin-1 promoter was linked to four genes involved in the biosynthesis of plant lignans and the four constructs were co-introduced by particle bombardment. Over $50 \%$ of the resulting transgenic plants contained all four genes, and in most of these plants the seeds produced higher lignan levels than controls. Lignans are present in non-transgenic rice endosperm tissue at levels lower than $1 \mathrm{pg} \mathrm{mg}^{-1}$, and a 50 -fold increase was achieved in the best-performing transgenic grains (Huang, unpublished data). Romano and colleagues synthesized polyhydroxyalkanoates (PHAs) in transgenic potatoes by simultaneously introducing the $p h a \mathrm{G}$ and pha $\mathrm{C}$ genes encoding acyl-CoA transacylase and PHA polymerase along with the neomycin-phosphotransferase selectable marker in three separate constructs (Romano et al. 2005). In cassava (Raemakers et al. unpublished results) two genes involved in the starch biosynthetic pathway were silenced via cotransformation with antisense constructs, with the aim of producing high-amylose starch.

In addition to applications in metabolic engineering and multi-gene resistance strategies, the direct transfer of multiple genes has also become a practical strategy for generating crops that produce multimeric proteins. For example, Nicholson et al. (2005) have produced full sized multimeric antibodies in transgenic plants. These proteins comprise at least two components, the heavy and light chains, but more complex antibody forms such as secretory antibodies ( $\operatorname{sg} \mathrm{A})$ also require a joining chain and a secretory component. In order to produce such molecules in transgenic plants, all four components must be produced simultaneously in the same host cell. Transgenic tobacco plants have been generated expressing such secretory antibodies by the laborious process of individual transformation by $A$. tumefaciens followed by successive rounds of sexual crossing to stack all four transgenes in the same plant line (Ma et al. 1994). In contrast, Nicholson et al. (2005) have simultaneously delivered all four genes, together with a fifth gene encoding a selectable marker, into rice by particle bombardment. Numerous independent transgenic rice plants were recovered from such cotransformation experiments, and lines expressing various combinations of the recombinant immunoglobulin components were identified. Fifteen combinations of integrated transgenes were recovered, only three of which should have the potential to produce a protein with antigen-binding potential: monomeric $\operatorname{IgA}$ (heavy and light chains only), dimeric IgA (heavy and light chains with joining chain) and secretory IgA (all four components). From a representative population of 64 transgenic rice lines studied in depth, 12 lines (19\%) expressed all four immunoglobulin components in addition to the selectable marker, while dimeric IgA was detected in three further lines $(5 \%)$ and monomeric $\operatorname{IgA}$ was detected in one line $(2 \%)$. These data suggest that, where multiple transgenes are involved, multi-gene transformation is favored over single gene transformation.

The engineering of improved bread-making quality in rye also requires multigene transformation, in this case the introduction of multiple highand low-molecular-weight glutenin subunit genes. These subunits support the formation of gluten, the largest known protein polymer, which forms a continuous proteinacious network during dough mixing, thus affecting dough strength and bread loaf volume. Transgenic rye plants have been produced by particle bombardment with several 
glutenin subunit genes. The stable expression of between one and three glutenin subunits at levels up to $16 \%$ of the total extracted rye flour protein has a dramatic effect on storage protein polymerization and end use properties (Altpeter et al. 2004b). This is an important step towards improving bread-making properties of rye while conserving its superior stress resistance. Transgenic wheat plants produced by particle bombardment, and expressing high-molecular-weight glutenin subunits under field conditions, have also been reported (Altpeter et al. 1996b; Vasil et al. 2001).

One of the most interesting recent developments of particle bombardment is the combination of multiple gene transfer and clean DNA techniques, i.e. the simultaneous transfer of multiple gene cassettes into rice plants. The original report by $\mathrm{Fu}$ et al. (2000) provided preliminary evidence that cotransformation with two separate cassettes encoding the marker genes gus A and $h p t$ was at least as efficient as cotransformation with whole plasmids, and at the same time preserved the simpler integration patterns observed for the single-cassette transformants. These results were confirmed using the $y f p$ (yellow fluorescent protein) and $h p t$ markers by Breitler et al. (2002), who noted that concatemers were formed only rarely in such plants. Loc et al. (2002) used the cassette strategy to introduce three genes into rice plants, the marker gene $h p t$ and (for the first time) two genes of agronomic importance - gna encoding the Galanthus nivalis agglutinin (a lectin that is toxic to homopteran insect pests) and crylAc encoding a Bacillus thuringiensis ( $\mathrm{Bt})$ endotoxin, which is active against lepidopteran pests. As above, these investigators noted that the cassette transformation method was at least as efficient as wholeplasmid transformation, but that the former resulted in higher levels of recombinant protein. Most recently, Agrawal et al. (in press) have carried out particle bombardment with five separate marker gene cassettes (gusA, bar, hpt, luc and as). The cassettes were shown to be very efficient substrates for multi-transgene cotransformation, with all transgenic plants containing at least two transgenes and $16 \%$ containing all five. The total number of different transgenes introduced into the plants showed a near normal distribution and about $75 \%$ of the plants had simple transgene integration patterns with a predominance of single-copy insertions. The expression levels for all transgenes, and the overall coexpression frequencies, were much higher than previously reported in whole plasmid transformants generated either by particle bombardment or Agrobacterium-mediated transformation. In the vast majority of lines these high expression levels were stable over several generations. Similarly, Romano et al. (2003a) showed that while 17 and $45 \%$ of potato plants bombarded with three plasmids (containing a selectable marker and two non-selected genes) were co-transformed with two and three genes, respectively, $75 \%$ of plants bombarded with multiple cassettes were co-transformed.

\section{The structure of transgenic loci and the impact on transgene expression}

Transgene integration, mediated by either A. tumefaciens or particle bombardment, is a random process that appears to correlate with the position of naturally occurring chromosome breaks. Transcriptionally active regions of the genome are favored, particularly the sub-terminal regions of the chromosomes, perhaps because the DNA is more accessible in these areas. It is possible, although still a matter of speculation, that further breaks may be caused by particle bombardment since the microprojectiles may shear the ends of DNA loops in the nucleus (Abranches et al. 2000; Kohli et al. 2003). This may go some way to explaining the relative efficiency of bombardment in terms of stable transformation compared to other techniques.

It is a widely held belief that particle bombardment produces large, multi-copy, and highly complex transgenic loci that are prone to further recombination, instability and silencing. While it may be true that the delivery of whole plasmids by particle bombardment can lead to an increased proportion of complex transformation events compared to Agrobacterium-mediated transformation (e.g. see Dai et al. 2001 for a direct comparison of the two methods which reached this conclusion), recent experiments have shown that particle bombardment can be tuned to favor the generation of plants with simple transgenic loci containing a small number of intact transgene copies. It should also be emphasized that 
comparisons between the two methods that have led to this belief did not take into account the frequency with which plasmid backbones are delivered during T-DNA transfer, which significantly reduces the reported frequency of clean events produced by Agrobacterium-mediated transformation (Ramanathan and Veluthambi 1995; van der Graaf et al. 1996; Kononov et al. 1997; Wenck et al. 1997; McCormac et al. 2001; Popelka and Altpeter 2003a). Even where multiple copies are present, the adage that higher copy numbers correspond to lower expression levels does not stand up to close scrutiny. In rice and potato, for example, we have found that single-copy insertions and multiple insertions can be produced in equal measure even when whole plasmids are used (Datta et al. 1998, 2003; Tu et al. 1998a, b; Romano et al. 2003a). The multiple copies can exist either as tandem or inverted repeats, with intact or fragmented transgenes. Experience with Golden rice (Datta et al. 2003) suggests that higher transgene copy numbers correspond to higher expression levels, ultimately leading to more $\beta$-carotene production in the endosperm. Bt rice with more than one copy of the transgene also performed well under field conditions against a number of insect pests, indicating that the transgenes were expressed efficiently ( $\mathrm{Tu}$ et al. 2000b; Ye et al. 2001). Similar observations of high expression levels have been reported in transgenic wheat transformed with multiple copies of reporter genes (Stoger et al. 1998).

Another direct comparison of gene transfer by particle bombardment and Agrobacterium-mediated transformation has been carried out by Altpeter et al. (2004a). These investigators assessed the transgene integration pattern, plant fertility and stability of transgene expression after vegetative and sexual reproduction was carried out with a large number of independently transformed perennial ryegrass plants. The majority of transgenic lines from both bombardment and Agrobacterium-mediated gene transfer had simple transgene integration patterns with between one and four transgene copies. The plants were fertile and the transgene was stably expressed in sexual and vegetative progenies. Only a small subset (approximately 20\%) of the ryegrass lines generated by particle bombardment had very complex integration patterns (between five and 20 transgene copies) while none of the lines generated by Agrobacterium-mediated gene transfer had more than five T-DNA inserts. Gene silencing after sexual reproduction or one year of vegetative reproduction was observed most frequently in the lines with five or more transgene copies, but approximately $50 \%$ of these high-copy-number lines stably expressed the transgene (Altpeter et al. 2004a). These data suggest that both gene transfer systems have a similar potential to produce fertile and stably-expressing transgenic perennial ryegrass lines. Notably, however, the particle bombardment protocol is applicable to a wide range of turf- and forage-type genotypes (Altpeter et al. 2000), while Agrobacterium-mediated ryegrass transformation appears to be limited to a few responsive ryegrass genotypes.

Regarding the issue of transgene copy number and protein expression levels, the data provided by Huang and colleagues ( $\mathrm{Tu}$ et al. 2000b; Ye et al. 2001) show an interesting counterpoint to the current, seemingly obsessive fascination with low-copy-number transgenic plants. When using rice plants to produce pharmaceuticals and nutriceuticals, the expression level of the recombinant protein is absolutely critical since this dictates the economics of downstream processing. For example, Nandi et al. (2002) have achieved levels of approximately $5 \mathrm{mg}$ human lactoferrin per gram of flour and have estimated production costs at approximately $\$ 6$ per gram of pharmaceutical-grade protein. If the expression level dropped to $0.5 \mathrm{mg}$ or $0.05 \mathrm{mg} \mathrm{g}^{-1}$, the cost would increase to $\$ 60$ and $\$ 400$ per gram, respectively. The overall value of nutriceuticals is lower than that of pharmaceuticals, making production commercially unfeasible under low expression regimes. Therefore, the level of protein expression is the first criterion for the selection of breeding lines. Our experience shows that, regardless the transformation method, lines selected for high recombinant protein expression levels tend to contain three or more transgene copies. Therefore, despite the pervasive lore in plant biotechnology suggesting that low transgene copy number is required for high-level expression, evidence from the authors' laboratories suggests that the opposite is in fact the case. However, each expression cassette should be intact. The presence of one or more rearranged copies can potentially lead to transgene silencing even if the other copies are intact and functional (Kohli et al. 1999a). 
Multi-copy transgenic plants generated by particle bombardment tend to have all the transgene copies at a single locus, regardless of how many different transformation cassettes have been used. In contrast, Agrobacterium-mediated transformation tends to disperse transgenes to more than one locus. Although the latter allows selectable markers to be segregated, larger populations of plants (or more generations of plants) are required to achieve homozygosity. When transferring the transgenes into a new genetic background via traditional breeding, breeding lines carrying the same gene at multiple loci are more difficult to use than those where all the genes are present at the same locus. In this respect, particle bombardment is advantageous over Agrobacterium-mediated transformation.

In order to address concerns about copy number, transgene organization and transgene silencing, a number of studies have been undertaken to characterize large numbers of transgenic cereal plants transformed by particle bombardment. Very soon after these studies began, it was realized that the key to a better understanding lay in characterizing the transgenic loci in detail, addressing a number of questions such as the following:

- How many transgene copies are integrated?

- In the case of multiple copies, are the copies integrated together or dispersed?

- Are the integrated copies intact, truncated or rearranged?

- Is there any preferential site in the genome for transgene integration?

- How are the transgenes organized at the chromatin level?

- Do transgenes behave differently in different genetic backgrounds?

- What is the cytosine methylation status of expressing and non-expressing transgenes, and of silenced and reactivated transgenes?

- What is the status of expression/silencing at the levels of transcription and translation?

- How stable is the expressed/silenced phenotype and is this status transferred within the plant and from one generation to the other.

Over the last decade, all of the above issues have been addressed and although much still remains to be discovered, a definitive picture of the usefulness of particle bombardment as a tool for effective plant transformation beyond model species has emerged. A two-phase model of transgene integration in rice has been proposed, based on particle bombardment with whole plasmids (Kohli et al. 1998). The salient finding was that an array of integrated transgenes, genetically segregating as a single unit, could be interrupted with genomic DNA. This was found to be the case in transgenic rice (Kohli et al. 1999b) oat (Pawlowski and Somers 1998; Svitashev et al. 2000, 2002; Svitashev and Somers 2001; Makarevitch et al. 2003) maize (Mehlo et al. 2000) wheat (Abranches et al. 2000; Jackson et al. 2001) and potato (Romano et al. 2003b). These studies made it remarkably clear that transgenes can undergo rearrangements before or during integration into the host genome. Fine resolution characterization of the kind of rearrangements in transgenes (Kohli et al. 1999b) and at the genomic site of integration (Makeravitch et al. 2003; Sawasaki et al. 1998; Svitashev et al. 2002) revealed similarities with integration mechanisms proposed for Agrobacterium-mediated transformation.

The molecular evidence for transgene organization has been supplemented with physical mapping data using fluorescence in situ hybridization (FISH). Such studies have been carried out mainly in cereals with large nuclei and chromosomes, such as wheat (Abranches et al. 2000; Jackson et al. 2001) and oat (Svitashev et al. 2000; Svitashev and Somers 2001), although there were also experiments in rice (Dong et al. 2001). Following these studies, Kohli et al. (2003) proposed a hierarchical model of transgene organization:

- Multiple copies of the same or different transgenes often form concatemers prior to integration, without any interspersed genomic DNA. This is particularly evident in whole plasmid transformants, where there are extensive regions of homology interspersed with elements showing strong recombinogenic tendencies.

- Single copies and concatemers integrate in a local cluster, interspersed with short segments (kilobases) of genomic DNA. The cluster can be regarded as a continuance of the same integration event. 
- Several clusters may exist separated by megabases of genomic DNA, yet still behave as a single segregating unit at the genetic level.

- Single copies, concatemers and clusters may integrate independently at more than one position, either on the same chromosome or on different chromosomes, and hence segregate as independent loci. At the International Rice Research Institute, The Philippines, researchers have been successful in obtaining marker-free transgenic $\mathrm{Bt}$ rice through the identification of segregants lacking the marker gene locus. This segregated from the locus containing the Bt gene (Tu et al. 2003).

- The overall three dimensional organization of transgenic loci must be considered at the chromatin level. In this respect, transgenic loci that appear to lie far apart when metaphase chromosomes are stained using the FISH technique may in fact be very close together in space when the same technique is applied to interphase chromatin (Abranches et al. 2000).

All the transgenic rice lines described above were also studied in terms of transgene expression. As stated above, many plants with higher copy numbers showed higher expression levels at least until the $\mathrm{R}_{3}$ generation, when the analysis ceased (Kohli et al. 1999a). Many of the poor-expressers with high copy numbers showed deleterious rearrangements, which could give rise to aberrant RNA molecules responsible for post-transcriptional silencing. As long as intact transgene integration occurred, the copy number was not critical for a variety of genes expressed in different genotypes of rice, ryegrass, fescue, rye and wheat (Altpeter and Xu 2000; Altpeter et al. 2000, 2004a; Gahakwa et al. 2000; Varshney and Altpeter 2001; Popelka and Altpeter 2003b). The same trend was shown for transgenic potato, where expression of the gus A reporter gene varied, but with no respect to the copy number or the number of integration sites (Romano et al. 2003a, b). In a practical sense, what emerges from these studies is that particle bombardment can be used to produce plants either with low copy numbers or high copy numbers, and plants containing either single transgene copies or concatemers. This unique versatility means that the advantages of single copy or multi-copy transgenes and of single loci or multiple segregating loci can be exploited for different purposes.

\section{High molecular weight DNA delivery into plant cells}

Until recently, one serious limitation to plant transformation technology was the inability to introduce large intact DNA constructs into the plant genome. Such large constructs could incorporate multiple transgenes, or could comprise a segment of genomic DNA to facilitate the map-based cloning of plant genes. In Agrobacterium-mediated transformation, this limitation has been addressed by the development of BIBAC and TAC vectors (Shibata and Liu 2000). The transfer of YAC DNA by particle bombardment was first demonstrated by Vaneck et al. (1995) using cell suspensions of two tomato cultivars. Only one of the cultivars yielded YAC transformants, and initial studies suggested that the integrated YAC was 'fairly intact' in four of the five transformants recovered, based on the presence of two marker genes. The use of YACs retrofitted with two plant selectable markers, such as $n p t I I$ and $h p t$, provides a quick and reliable method to verify the presence of both YAC arms in transgenic tissues (Adam et al. 1997). The transfer of YACs to tobacco cell suspension cultures by particle bombardment was verified in this manner, by testing for simultaneous resistance to kanamycin and hygromycin. YACs ranging in size from 80 to $550 \mathrm{~kb}$ were tested (Mullen et al. 1998). Twelve kanamycin-resistant calli were recovered from cell suspensions transformed with the $80-\mathrm{kb}$ YAC. Ten of these were hygromycin-sensitive and contained only a short portion of the nptII-retrofitted YAC arm in addition to the marker. The two remaining calli were hygromycin resistant. These were tested with probes spanning the $55-\mathrm{kb}$ genomic insert of the YAC and one was found to have incorporated an intact single copy of the construct. Eight of 29 kanamycin-resistant transformants recovered from cell suspensions bombarded with a $150-\mathrm{kb}$ YAC were also found to be hygromycin resistant. Particle bombardment is therefore a relatively efficient procedure for generating high-molecularweight-DNA transformants, although it would be useful to compare data from a larger number of species. For example, in potato cv. Desiree, very high transformation frequencies were obtained using a small $(6.7-\mathrm{kb})$ plasmid, but it was difficult to obtain stable transformants using larger plasmids $(15-16 \mathrm{~kb})$ containing the same selectable 
marker, although the latter was efficient for Agrobacterium-mediated transformation.

\section{Structural and functional genomics}

Particle bombardment has featured strongly in the burgeoning field of cereal functional genomics, specifically through the development of transposon-tagged plant lines for the systematic functional characterization of plant genes. For example, Kohli et al. (2001, 2004) have produced a large population of transgenic rice plants tagged with the maize $A c$ transposon. They found that this population was suitable for saturation mutagenesis and the rapid PCR-based cloning of interrupted genes using unique barcode elements present in the DNA cassette used for transformation (Kohli et al. 2001). Callus induced from specific transposon-tagged rice plants was maintained in a dedifferentiated state prior to regeneration into clonal transgenic lines, prolonging the developmental phase characterized by hypomethylation of genomic DNA. This resulted in a dramatic increased frequency of secondary transposition events compared to seed-derived plants, thus increasing the rate of genome saturation (Kohli et al. 2004).

\section{Particle bombardment is the most convenient way to achieve organelle transformation}

Thus far, most genetically engineered plants have been subject to nuclear transformation. An alternative approach is to introduce transgenes into the chloroplast genome. This strategy offers advantages such as very high levels of transgene expression, uniparental plastid gene inheritance in most crop plants (preventing pollen transmission of transgenes), the absence of gene silencing and position effects, integration via a homologous recombination process that facilitates targeted transgene insertion, elimination of vector sequences, precise transgene control, and sequestration of foreign proteins in the organelle, which prevents adverse interactions within the cytoplasmic environment (Hager and Bock 2000; Bock 2001; Daniell 2002; Daniell et al. 2002, 2004a-c; Daniell and Dhingra 2002; Devine and Daniell 2004; Maliga 2004). Plastid transformation has been used to investigate chloroplast gene functions by reverse genetics (e.g. Ruf et al. 1997; Hager et al. 1999), but perhaps the most significant advances have been made in the production of chloroplast-transformed crop plants for trait modification and molecular farming. Transplastomic plants have been generated successfully to confer increased pest resistance (McBride et al. 1995; Kota et al. 1999; DeCosa et al. 2001), herbicide resistance (Daniell et al. 1998), disease resistance (De Gray et al. 2001), drought tolerance (Lee et al. 2003) and salt tolerance (Kumar et al. 2004b), and have also been used for phytoremediation (Ruiz et al. 2003) and metabolic engineering (Vitanen et al. 2004). Table 2 provides a list of all agronomic traits thus far engineered via the plastid genome using particle bombardment. The plastid genetic engineering approach has also been used for the expression of edible vaccines (Daniell et al. 2001a), monoclonal antibodies (Daniell 2004) and biopharmaceuticals (Daniell 1997; Guda et al. 2000; Staub et al. 2000; Fernandez-San Millan et al. 2003; Daniell et al. 2004a-c; Watson et al. 2004). Table 3 lists all the vaccines and biopharmaceuticals expressed thus far via the plastid genome using particle bombardment.

Table 2. Plastid transformation with agronomically useful genes, using particle bombardment

\begin{tabular}{|c|c|c|c|c|c|}
\hline Agronomic trait & Gene & Site of integration & Promoter & $5^{\prime} / 3^{\prime}$ regulatory elements & References \\
\hline Insect resistance & $\operatorname{cry} 1 \mathrm{~A}(\mathrm{c})$ & $\operatorname{trn} \mathrm{V} / r p s 12 / 7$ & Prrn & $r b c \mathrm{~L} / \mathrm{T} r p s 16$ & McBride et al. (1995) \\
\hline Herbicide resistance & aroA (petunia) & $r b c \mathrm{~L} / a c c \mathrm{D}$ & Prrn & ggagg/TpsbA & Daniell et al. (1998) \\
\hline Insect resistance & cry $2 \mathrm{Aa} 2$ & $r b c \mathrm{~L} / a c c \mathrm{D}$ & Prrn & ggagg (native)/TpsbA & Kota et al. (1999) \\
\hline Herbicide resistance & bar & $r b c \mathrm{~L} / a c c \mathrm{D}$ & Prrn & $r b c \mathrm{~L} / \mathrm{T} p s b \mathrm{~A}$ & Iamtham and Day (2000) \\
\hline Insect resistance & cry2Aa2 operon & $\operatorname{trn} \mathrm{I} / \operatorname{trn} \mathrm{A}$ & Prrn & native $5^{\prime} \mathrm{UTR}$ / $/ \mathrm{T} p s \mathrm{~A}$ & De Cosa et al. (2001) \\
\hline Disease resistance & MSI-99 & $\operatorname{trn} \mathrm{I} / \operatorname{trn} \mathrm{A}$ & Prrn & ggagg/TpsbA & DeGray et al. (2001) \\
\hline Drought tolerance & tps & $\operatorname{trn} \mathbf{I} \operatorname{trn} \mathrm{A}$ & Prrn & ggagg/TpsbA & Lee et al. (2003) \\
\hline Phytoremediation & mer $\mathrm{A} /$ mer $\mathrm{B}$ & $\operatorname{trn} \mathrm{I} / \operatorname{trn} \mathrm{A}$ & Prrn & ggagg/TpsbA & Ruiz et al. (2003) \\
\hline Salt tolerance & badh & $\operatorname{trn} \mathbf{I} / \operatorname{trn} \mathrm{A}$ & Prrn-F & ggagg/rps16 & Kumar et al. (2004b) \\
\hline
\end{tabular}




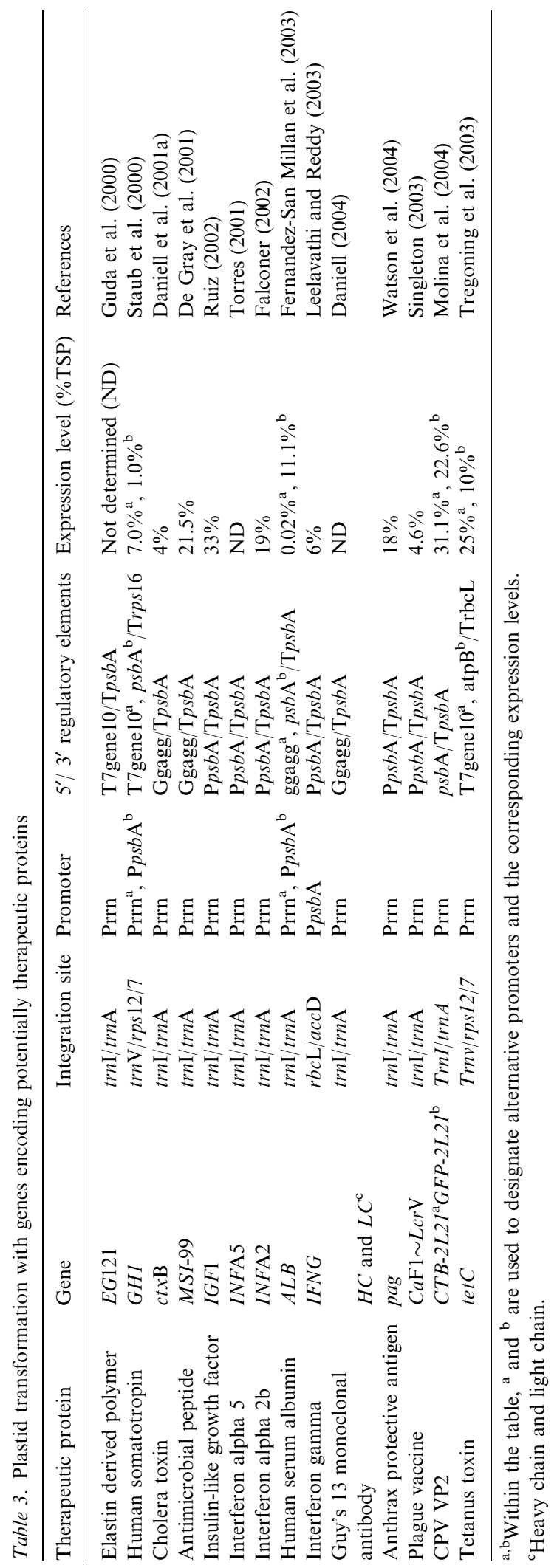


Several direct DNA transfer methods for transforming plastids have been developed, including particle bombardment (Svab et al. 1990; Svab and Maliga 1993) and PEG-mediated DNA uptake into protoplasts (Golds et al. 1993; O'Neill et al. 1993). The former method is favored because it is quicker, easier and more versatile (an efficient protoplast culture system is not required) and detailed methodologies for chloroplast genetic engineering using particle bombardment have been described (Bock 1998; Daniell 1997; Daniell et al. 2004d; Kumar and Daniell 2004). It is now possible to transform the chloroplast genome and then eliminate selectable marker genes after transgene integration (Iamtham and Day 2000; Corneille et al. 2001; Hajdukiewicz et al. 2001; Klaus et al. 2004). Furthermore, plastid mutations conferring tolerance to antibiotics through alterations in ribosome structure can be used as an alternative to bacterial antibiotic resistance genes for the selection of plastid transformants (Kavanagh et al. 1994; Dix and Kavanagh 1995), although such mutations have been used mostly in conjunction with protoplast transformation rather than particle bombardment (O'Neill et al. 1993; Kavanagh et al. 1999).

The first successful plastid transformation by particle bombardment was achieved over 15 years ago, when Boynton et al. (1988) reported the complementation of a chloroplast mutant in the green alga Chlamydomonas reinhardtii. The single large chloroplast in these cells provided an ideal target for DNA delivery. The mutant algae carried a deletion in the atpB gene, and thus lacked chloroplast ATP synthase activity. The wild type $a t p \mathrm{~B}$ gene was introduced into cultured algal cells using tungsten microprojectiles, restoring photoautotrophic growth. The transgene resided within a chloroplast homology region, and integrated via homologous recombination. Later, the same technique was used to introduce a foreign marker gene, gusA. However, while transcription of the integrated transgene was demonstrated, the protein could not be detected (Blowers et al. 1989). At this time, it was impossible to introduce foreign DNA into higher plant chloroplasts without first isolating them from the cell (Daniell and McFadden 1987). The first report of foreign gene expression in the plastids of cultured tobacco cells involved the use of autonomously replicating chloroplast vectors (Daniell et al. 1990). This work was repeated using wheat leaves, callus and somatic embryos
(Daniell et al. 1991). A mutant tobacco $16 S$ rRNA gene was used for stable complementation in these experiments (Svab et al. 1990) but continuing work with $C$. reinhardtii chloroplast transformation led to the development of the $\operatorname{aadA}$ gene as a selectable marker conferring spectinomycin or streptomycin resistance (Goldschmidt-Clermont 1991). The majority of chloroplast transformation experiments in higher plants now involve this selectable marker. Stable integration of aadA into the tobacco chloroplast genome was demonstrated by Svab and Maliga (1993).

Among crop plants, tobacco, tomato (Ruf et al. 2001) and potato (Sidorov et al. 1999; Nguyen unpublished data) chloroplasts have been transformed, as well as three Brassicacea species Brassica napus (oilseed rape; Hou et al. 2003), $B$. oleracea var. Botrytis (cauliflower; Gregory Nugent unpublished data) and Lesquerella fendleri (Skarjinskaia et al. 2003). However, in B. napus, it has so far been impossible to achieve homoplasmy (which is required to confirm stable integration) and maternal inheritance (to confirm transmission of the transgene to subsequent generations). Most recently, soybean plastid transformation has been achieved (Dufourmantel et al. 2004). The major limitations in transforming the chloroplasts of other crop species, especially monocots, include a poor understanding of gene expression in nongreen plastids, gene delivery methods for proplastids and tissue culture conditions. So far, chloroplast transformation by particle bombardment has been achieved only in crops that allow direct organogenesis. A consequence of the use of dominant selectable markers is that non-transformed plastome copies present in the same plastid or cell are not readily eliminated. This means that two or more regeneration and selection cycles are frequently required to establish homoplasmy, although this is not always the case (Guda et al. 2000; Nguyen unpublished data). The ability to achieve homoplasmy in the absence of a second round of regeneration, especially in crops that regenerate via embryogenesis is yet another challenge for chloroplast genetic engineering (Khan and Maliga 1999). However, these hurdles have recently been overcome. Efficient plastid transformation using non-green tissues has been accomplished in carrot where chloroplast transgenic lines were generated via somatic embryogenesis from tissues containing proplastids (Kumar et al. 
2004b). Transgene expression under the control of heterologous regulatory sequences was achieved at a frequency of approximately $75 \%$ in non-green carrot tissues containing chromoplasts (i.e. the taproot, which grows underground) and $48 \%$ in proplastids of cultured cells, compared to $100 \%$ in leaf chloroplasts (Kumar et al. 2004b). Betaine aldehyde dehyrogenase (BADH) enzyme activity was enhanced eightfold in transgenic carrot cell cultures, which grew sevenfold more quickly and accumulated 50-54-fold more betaine (93-101 $\mu \mathrm{mol} \mathrm{g}^{-1}$ DW of $\beta$-alanine betaine and glycine betaine) than untransformed cells grown in liquid medium containing $100 \mathrm{mM} \mathrm{NaCl}$. Transgenic carrot plants expressing BADH grew in the presence of high concentrations of $\mathrm{NaCl}$ (up to $400 \mathrm{mM}$ ), the highest level of salt tolerance reported so far among genetically modified crop plants. This demonstration of plastid transformation via somatic embryogenesis, utilizing nongreen tissues as the recipient of foreign DNA, for the first time overcomes two of the major obstacles in extending this technology to important crop plants. Similarly, by employing the 'double gene single selection (DGSS)' plastid transformation vector, which contains two selectable marker genes (aph $\mathrm{A} 6$ and $n p t \mathrm{II})$ driven by green and non-green regulatory signals to detoxify the same antibiotic using two enzymes, cotton plastid transformation was achieved irrespective of the type of tissues or plastids used (Kumar et al. 2004a). The DGSS transformation vector was at least eight-fold more efficient (one event per 2.4 bombarded plates) than the 'single gene single selection (SGSS)' vector containing the aphA6 gene. The chloroplast transgenic lines were fertile, and they flowered and set seeds in a similar manner to non-transformed plants. The transgenes were stably integrated into the cotton chloroplast genome and were maternally inherited. They were not transmitted via pollen when out-crossed to non-transformed female plants (Kumar et al. 2004a).

Particle bombardment is currently the only way to transform mitochondrial genomes. Mitochondrial transformation was first achieved in yeast (Johnston et al. 1988) where it has become a routine technique (e.g. Fox et al. 1988; Anziano and Butow 1991; Steele et al. 1996; Sanchirico et al. 1998). At present, the green alga Chlamydomonas reinhardtii is the only plant whose mitochondrial genome is amenable to genetic manipulation
(Randolph-Anderson et al. 1993). Strenuous efforts are being made to develop mitochondrial transformation protocols for higher plants and, for the foreseeable future, particle bombardment will certainly continue to be the dominant technique for organelle transformation (Havey et al. 2002).

\section{Field evaluation of transgenic plants developed by particle bombardment}

Transgenic plants generated by particle bombardment have not been restricted to the laboratory or greenhouse. Several publications over the last few years have documented the successful field evaluation of such transgenic crops, including herbicideresistant soybean, insect-resistant corn and cotton, fungus-resistant wheat, and rice resistant to bacterial blight and lepidopteran insect pests. As an example, we describe here the successful deployment of transgenic rice lines, created by particle bombardment at IRRI, carrying the $X a 21$ gene for bacterial blight resistance and the Bt crylAbcryl $A c$ fusion gene for resistance to lepidopteran insects. The Bt line has been field-tested both in China (Tu et al. 2000a, b; Ye et al. 2001) and in India (Datta et al. 2002). Transgenic cultivar IR72, containing the Bt fusion gene, showed excellent resistance against four insect pests (yellow stem borer, stripped stem borer, pink stem borer and leaf-folder) under field conditions following both manual and natural infestations (Ye et al. 2001). The Bt hybrid rice also has a yield advantage of about $30 \%$ over the non-transgenic hybrid ( $\mathrm{Tu}$ et al. 2000b). Multiple transgene copies and rearrangement within the transgenic locus did not affect the phenotype or yield of the plants. This Bt-hybrid rice does not contain any antibiotic resistance markers and is scheduled for field release in China in the near future. Several other transgenic rice lines, generated by particle bombardment and developed for biotic or abiotic stress tolerance or for nutritional improvement (e.g. elevated levels of provitamin A and iron) are already at the advanced regulatory phase for field evaluation.

\section{Concluding comments}

Particle bombardment remains a uniquely advantageous transformation method, and indeed the 
only one available for many species. The absence of biological constraints (host-range, genotype dependence) and the ability to target any cell type, even in intact organized tissues, means that the method is uniquely versatile. Therefore, in some crops, elite commercial varieties are amenable to transformation without extensive backcrossing, which is normally required in other transformation systems to introgress genes from amenable model varieties into elite cultivars. The ability to target organized tissues reduces or eliminates the requirement for tissue culture, and therefore limits the occurrence of somaclonal variation, which can lead to infertility and morphological abnormalities in transgenic plants. Although there is widespread belief that particle bombardment generates large, multi-copy loci prone to instability and silencing, refinements of the technology to produce clean transgene loci have demonstrated clearly that this is not the case, and that particle bombardment has many advantages for the production of commercial transgenic plants that perform well in the field and comply with all relevant regulatory processes. We conclude that particle bombardment is likely to continue to play an important role in plant biology and crop biotechnology for many years into the future.

\section{Acknowledgements}

PC acknowledges long-term financial support from the Rockefeller Foundation and the European Union (QLRT-2000-01453 and LHSB-CT2003-503565). SD acknowledges financial support from the Rockefeller Foundation, DANIDA, BMZ/GTZ and USAID. FA acknowledges financial support from CPBR, USDA, European Union, BMBF, DFG, DAAD and the Alexander von Humboldt Foundation. AR, KR and RV acknowledge funding by the EU FAIR Programme (FAIR/CT96-1780), an EU Marie Curie Fellowship (FAIR/CT98-5036), an Agrotechnology and Food Innovations IAC grant and by the Dutch Ministry of Agriculture, Nature Management and Fisheries (LNV, DWK programme 345): 'Verwerking duurzame agromaterialen (milieuvriendelijke agrificatie)'. Work in RB's laboratory is funded by grants from the Deutsche Forschungsgemeinschaft and the European Union. PD acknowledges support from EU 5th
Framework Programme (QLK-1999-00692) and the Science Foundation Ireland. Investigations in the Daniell laboratory were supported in part by funding from NIH R 01 GM63879 and USDA 3611-21000-017-00D grants.

\section{References}

Abranches R., Santos A.P., Williams S., Wegel E., Castilho A., Christou P., Shaw P. and Stoger E. 2000. Widely-separated multiple transgene integration sites in wheat chromosomes are brought together at interphase. Plant J. 24: 713-723.

Adam G., Mullen J.A. and Kindle K.L. 1997. Retrofitting YACs for direct DNA transfer into plant cells. Plant J. 11: 1349-1358.

Agrawal P.K., Kohli A., Twyman R.M. and Christou P. 2004. Multiple gene transfer with minimal expression cassettes promotes independent cointegration and stable coexpression in transgenic rice plants. Mol. Breeding in press.

Alam M.F., Datta K., Vasquez A., Tu J., Virmani S.S. and Datta S.K. 1999. Transgenic insect resistant maintainer line (IR68899B) for improvement of hybrid rice. Plant Cell Rep. 18: $572-575$.

Altpeter F. and $\mathrm{Xu}$ J. 2000. Rapid production of transgenic turfgrass (Festuca rubra L.) plants. J. Plant Physiol. 157: 441448 .

Altpeter F., Vasil V., Srivastava V., Stoger E. and Vasil I.K. 1996a. Accelerated production of transgenic wheat (Triticum aestivum L.) plants. Plant Cell Rep. 16: 12-17.

Altpeter F., Vasil V., Srivastava V. and Vasil I.K. 1996b. Integration and expression of the high molecular weight glutenin subunit 1Ax1 into wheat. Nature Biotechnol. 14: 1155-1159.

Altpeter F., Xu J. and Ahmed S. 2000. Generation of large numbers of independently transformed fertile perennial ryegrass (Lolium perenne L.) plants of forage- and turf type cultivars. Mol. Breeding 6: 519-528.

Altpeter F., Fang Y.-D., Xu J. and Ma X.R. 2004a. Comparison of transgene expression stability after Agrobacteriummediated or biolistic gene transfer into perennial ryegrass. In: Hopkins A., Wang Z.Y., Mian R., Sledge M. and Barker R. (eds), Molecular Breeding of Forage and Turf. Kluwer Academic Publishers, Dordrecht The Netherlands, pp. 255260.

Altpeter F., Popelka J.C. and Wieser H. 2004b. Stable expression of $1 D x 5$ and $1 D y 10$ high-molecular-weight glutenin subunit genes in transgenic rye, drastically increases the polymeric glutelin fraction in rye flour. Plant Mol. Biol. 54: 783-792.

Anziano P.Q. and Butow R.A. 1991. Splicing-defective mutants of the yeast mitochondrial coxI gene can be corrected by transformation with a hybrid maturase gene. Proc. Natl. Acad. Sci. USA 88: 5592-5596.

Baisakh N., Datta K., Oliva N., Ona I., Rao G.J.N., Mew T.W. and Datta S.K. 2001. Rapid development of homozygous transgenic rice using anther culture harboring rice chitinase gene for enhanced sheath blight resistance. Plant Biotechnol. 18: $101-108$. 
Balachandran S., Chandel G., Alam M.F., Tu J., Virmani S.S., Datta K. and Datta S.K. 2003. Improving hybrid rice through anther culture and transgenic approaches. In: Virmani S.S., Mao C.X. and Harby B. (eds), Proceedings of the 4th International Symposium on Hybrid Rice for Food Security, Poverty Alleviation and Environmental Protection. Hanoi, Vietnam, and IRRI, The Philippines, pp. 105-118.

Bassie L., Noury M., Lepri O., Lahaye T., Christou P. and Capell T. 2000a. Promoter strength influences polyamine metabolism and morphogenic capacity in transgenic rice tissues expressing the oat $a d c$ cDNA constitutively. Transgenic Res. 9: 33-42.

Bassie L., Noury M., Wisniewski J.P., Topsom L., Christou P. and Capell T. 2000b. Transgenic rice cell lines as a useful tool to study the biochemistry of down-regulation of an endogenous rice gene using a heterologous diamine-oxidase cDNA. Plant Physiol. Biochem. 38: 729-737.

Blowers A.D., Bogorad L., Shark K.B. and Sanford J.C. 1989. Studies on Chlamydomonas chloroplast transformation: foreign DNA can be stably maintained in the chromosome. Plant Cell 1: 123-132.

Bock R. 1998. Analysis of RNA editing in plastids. Methods 15: 75-83.

Bock R. 2001. Transgenic chloroplasts in basic research and plant biotechnology. J. Mol. Biol. 312: 425-438.

Boynton J.E., Gillham N.W., Harris E.H., Hosler J.P., Johnson A.M. and Jones A.M. et al. 1988. Chloroplast transformation in Chlamydomonas with high velocity microprojectiles. Science 240: 1534-1538.

Breitler J.C., Labeyrie A., Meynard D., Legavre T. and Guiderdoni E. 2002. Efficient microprojectile bombardmentmediated transformation of rice using gene cassettes. Theor. Appl. Genet. 104: 709-719.

Briddon R., Liu S., Pinner M. and Markham P. 1998. Infectivity of African cassava mosaic virus by biolistic incolulation. Arch. Virol. 143: 2487-2492.

Capell T., Bassie L., Topsom L., Hitchin E. and Christou P. 2000. Simultaneous down-regulation of two related enzymes in early steps of the polyamine biosynthetic pathway in transgenic rice by a single antisense mRNA species. Mol. Gen. Genet. 264: 470-476.

Capell T., Bassie L. and Christou P. 2004. Modulation of the polyamine biosynthetic pathway in transgenic rice confers tolerance to drought stress. Proc. Natl. Acad. Sci. USA 101: 9909-9914.

Capell T., Escobar C., Liu H., Burtin D., Lepri O. and Christou P. 1998. Over-expression of the oat arginine decarboxylase cDNA in transgenic rice (Oryza sativa L.) affects normal development patterns in vitro and results in putrescine accumulation in transgenic plants. Theor. Appl. Genet. 97: 246-254.

Chakraborty S., Pandey P.K., Banerjee M.K., Kalloo G. and Fauquet C.M. 2003. Tomato leaf curl Gujarat virus, a new Begomovirus species causing a severe leaf curl disease of tomato in Varanasi, India. Phytopathology 93: 1485-1494.

Chellappan P., Masona M.V., Vanitharani R., Taylor N.J. and Fauquet C.M. 2005. Broad spectrum resistance to ssDNA viruses associated with transgene-induced gene silencing in cassava. Plant Mol. Biol. in press.

Chen L., Marmey P., Taylor N.J., Brizard J., Espinoza C., D’Cruz P., Huet H., Zhang S., de Kochko A., Beachy R.N. and Fauquet C.M. 1998. Expression and inheritance of multiple transgenes in rice plants. Nature Biotechnol. 16: 1060-1064.

Christou P., Ford T.L. and Kofron M. 1991. Genotype-independent stable ransformation of rice (Oryza sativa) plants. Bio/Technology 9: 957-962.

Christou P., Ford T.L. and Kofron M. 1992. Rice genetic engineering: a review. Trends Biotechnol. 10: 239-246.

Clarke B.C. and Appels R. 1998. A transient assay for evaluating promoters in wheat endosperm tissue. Genome 41: 865-871.

Corneille S., Lutz K., Svab Z. and Maliga P. 2001. Efficient elimination of selectable marker genes from the plastid genome by the Cre-lox site-specific recombination system. Plant J. 27: 171-178

Crossway A., Oakes J.V., Irvine J.M., Ward B., Knauf V.C. and Shewmaker C.K. 1986. Integration of foreign DNA following microinjection of tobacco mesophyll protoplasts. Mol. Gen. Genet. 202: 179-185.

Dai S.H., Zheng P., Marmey P., Zhang S.P., Tian W.Z., Chen S.Y., Beachy R.N. and Fauquet C. 2001. Comparative analysis of transgenic rice plants obtained by Agrobacteriummediated transformation and particle bombardment. Mol. Breeding 7: 25-33.

Daniell H. 1997. Transformation and foreign gene expression in plants mediated by microprojectile bombardment. Methods Mol. Biol. 62: 453-488.

Daniell H. 2002. Molecular strategies for gene containment in transgenic crops. Nature Biotechnol. 20: 581-586.

Daniell H. 2004. Medical molecular pharming: Therapeutic recombinant antibodies, biopharmaceuticals, and edible vaccines in transgenic plants engineered via the chloroplast genome. In: Goodman R.M. (ed.), Encyclopedia of Plant and Crop Science. Marcel Decker, New York, pp. 704-710.

Daniell H. and Dhingra A. 2002. Multigene engineering: dawn of an exciting new era in biotechnology. Curr. Opin. Biotechnol. 13: 136-171.

Daniell H. and McFadden B.A. 1987. Uptake and expression of bacterial and cyanobacterial genes by isolated cucumber etioplasts. Proc. Natl. Acad. Sci. USA 84: 6349-6353.

Daniell H., Vivekananda J., Nielsen B.L., Ye G.N., Tewari K.K. and Sanford J.C. 1990. Transient foreign gene expression in chloroplasts of cultured tobacco cells after biolistic delivery of chloroplast vectors. Proc. Natl. Acad. Sci. USA 87: 88-92.

Daniell H., Krishnan M. and McFadden B.F. 1991. Expression of $\beta$-glucoronidase gene in different cellular compartments following biolistic delivery of foreign DNA into wheat leaves and calli. Plant Cell Rep. 9: 615-619.

Daniell H., Datta R., Varma S., Gray S. and Lee S.B. 1998. Containment of herbicide resistance through genetic engineering of the chloroplast genome. Nature Biotechnol. 16: 345-348.

Daniell H., Lee S.B., Panchal T. and Weibe P.O. 2001a. Expression of the native cholera toxin B subunit gene and assembly as functional oligomers in transgenic chloroplasts. J. Mol. Biol. 311: 1001-1009.

Daniell H., Muthukumar B. and Lee S.B. 2001b. Marker free transgenic plants: engineering the chloroplast genome without the use of antibiotic selection. Curr. Genet. 39: 109-116. 
Daniell H., Khan M.S. and Allison L. 2002. Milestones in chloroplast genetic engineering: an environmental friendly era in biotechnology. Trends Plant Sci. 7: 84-91.

Daniell D., Carmona-Sanchez O. and Burns B.B. 2004a. Chloroplast derived antibodies, biopharmaceuticals and edible vaccines. In: Fischer R. and Schillberg S. (eds), Molecular Farming. Wiley-VCH Verlag, Weinheim, Germany pp.113133.

Daniell H., Chebolu S., Kumar S., Singleton M. and Falconer R. 2004b. Chloroplast-derived vaccine antigens and other therapeutic proteins. Vaccine in press.

Daniell H., Cohill P., Kumar S. and Dufourmantel N. 2004c. Chloroplast genetic engineering. In: Daniell H. and Chase C. (eds), Molecular Biology and Biotechnology of Plant Organelles. Springer Publishers, Dordrecht, The Netherlands, pp. 423-468.

Daniell H., Ruiz O.N. and Dhingra A. 2004d. Chloroplast genetic engineering to improve agronomic traits. Methods Mol. Biol. 286: 111-137.

Datta K., Baisakh N., Oliva N., Torrizo L., Abrigo E., Tan J., Rai M., Rehana S., Al-Babili S., Beyer P., Potrykus I. and Datta S.K. 2003. Bioengineered 'golden' indica rice cultivars with beta-carotene metabolism in the endosperm with hygromycin and mannose selection systems. Plant Biotechnol. J. 1: 81-90.

Datta K., Baisakh N., Thet K.M., Tu J. and Datta S.K. 2002 Pyramiding transgenes for multiple resistance in rice against bacterial blight, yellow stem borer and sheath blight. Theor. Appl. Genet. 106: 1-8.

Datta K., Koukolíková-Nicola Z., Baisakh N., Oliva N. and Datta S.K. 2000. Agrobacterium-mediated engineering for sheath blight resistance of indica rice cultivars from different ecosystems. Theor. Appl. Genet. 100: 832-839.

Datta S.K., Peterhans A., Datta K. and Potrykus I. 1990. Genetically engineered fertile Indica-rice plants recovered from protoplasts. Bio/Technology 8: 736-740.

Datta K., Tu J., Oliva N., Ona I., Velazhahan R., Mew T.W., Muthukrishnan S. and Datta S.K. 2001. Enhanced resistance to sheath blight by constitutive expression of infection-related rice chitinase in transgenic elite indica rice cultivars. Plant Sci. 160: 405-414

Datta K., Vasquez A., Tu J., Torrizo L., Alam M.F., Oliva N., Abrigo E., Khush G.S. and Datta S.K. 1998. Constitutive and tissue-specific differential expression of $c r y I A(b)$ gene in transgenic rice plants conferring resistance to rice insect pest. Theor. Appl. Genet. 97: 20-30.

De Gray G., Rajasekaran K., Smith F., Sanford J. and Daniell H. 2001. Expression of an antimicrobial peptide via chloroplast genome control phytophatogenic bacteria and fungi. Plant Physiol. 127: 852-862.

DeCosa B., Moar W., Lee S.B., Miller M. and Daniell H. 2001. Hyper-expression of the Bt Cry2 Aa2 operon in chloroplasts leads to formation of insecticidal crystals. Nature Biotechnol. 19: 71-74.

Devine A.L. and Daniell H. 2004. Chloroplast genetic engineering. In: Moller S. (ed.), Plastids. Blackwell Science, Oxford, UK, pp. 283-320.

Dey M., Datta S.K., Torrizo L.B., Reddy P.M., Ladha J.K., Day B. and Stacey G. 1999. Integration into rice of a soybean apyrase gene proposed to play a central role in nodulation. Rice Genet. News 16: 145-147.
Dix P.J. and Kavangh T.A. 1995. Transforming the plastome: genetic markers and DNA delivery systems. Euphytica 85: 29-34.

Dong J.J., Kharb P., Teng W.M. and Hall T.C. 2001. Characterization of rice transformed via an Agrobacterium-mediated inflorescence approach. Mol. Breeding 7: 187-194.

Drakakaki G., Christou P. and Stoger E. 2000. Constitutive expression of soybean ferritin cDNA in transgenic wheat and rice results in increased iron levels in vegetative tissues but not in seeds. Transgenic Res. 9: 445-452.

Dufourmantel N., Pelissier B., Garc F., Peltier G., Ferullo J.M. and Tissot G. 2004. Generation of fertile transplastomic soybean. Plant Mol. Biol. 55: 479-489.

Falconer R. 2002 Expression of interferon alpha 2b in transgenic chloroplasts of a low-nicotine tobacco. M.S. thesis, University of Central Florida, Orlando, USA.

Fang Y.-D., Akula C. and Altpeter F. 2002. Agrobacteriummediated barley (Hordeum vulgare L.) transformation using green fluorescent protein as a visual marker and sequence analysis of the T-DNA:genomic DNA junctions. J. Plant Physiol. 159: 1131-1138.

Fernandez-San Millan A., Mingeo-Castel A.M., Miller M. and Daniell H. 2003. A chloroplast transgenic approach to hyperexpress and purify human serum albumin, a protein highly susceptible to proteolytic degradation. Plant Biotechnol. J. 1: 71-79.

Fofana I.B.F., Sangaré A., Collier R., Taylor C. and Fauquet C.M. 2005. A geminivirus-induced gene silencing system for gene function validation in cassava. Plant Mol. Biol. in press.

Fox T.D., Sanford J.C. and McMullin T.W. 1988. Plasmids can stably transform yeast mitochondria lacking endogenous mtDNA. Proc. Natl. Acad. Sci. USA 85: 7288-7292.

Frame B.R., Drayton P.R., Bagnall S.V., Lewnau C.J., Bullock W.P., Wilson H.M., Dunwell J.M., Thompson J.A. and Wang K. 1994. Production of fertile transgenic maize plants by silicon-carbide whisker-mediated transformation. Plant $\mathbf{J}$. 6: 941-948.

Fromm M.E., Taylor L.P. and Walbot V. 1986. Stable transformation of maize after gene-transfer by electroporation. Nature 319: 791-793.

Fu X.D., Duc L.T., Fontana S., Bong B.B., Tinjuangjun P., Sudhakar D., Twyman R.M., Christou P. and Kohli A. 2000. Linear transgene constructs lacking vector backbone sequences generate low-copy-number transgenic plants with simple integration patterns. Transgenic Res. 9: 11-19.

Gahakwa D., Maqbool S.B., Fu X., Sudhakar D., Christou P. and Kohli A. 2000. Transgenic rice as a system to study the stability of transgene expression: multiple heterologous transgenes show similar behavior in diverse genetic backgrounds. Theor. Appl. Genet. 101: 388-399.

Garrido-Ramirez E.R., Sudarshana M.R. and Gilbertson R.L. 2000. Bean golden yellow virus from Chiapas, Mexico: characterization, pseudorecombination with other beaninfecting geminivirues and germplasm screening. Phytopathology 90: 1224-1232.

Gelvin S.B. 2003. Agrobacterium-mediated plant transformation: the biology behind the "gene-jockeying" tool. Microbiol. Mol. Biol. Rev 67: 16-37.

Golds T., Maliga P. and Koop H.U. 1993. Stable plastid transformation in PEG-treated protoplasts of Nicotiana tabacum. Bio/Technology 11: 95-97. 
Goldschmidt-Clermont M. 1991. Transgenic expression of aminoglycoside adenine transferase in the chloroplast: a selectable marker for site-directed transformation of Chlamydomonas. Nucleic Acids Res. 19: 4083-4089.

Grosset J., Alary R., Gautier M.F., Menossi M., MartinezIzquierdo J.A. and Joudrier P. 1997. Characterization of a barley gene coding for an alpha-amylase inhibitor subunit (CMd protein) and analysis of its promoter in transgenic tobacco plants and in maize kernels by microprojectile bombardment. Plant Mol. Biol. 34: 331-338.

Guda C., Lee S.B. and Daniell H. 2000. Stable expression of biodegradable protein base polymer in tobacco chloroplasts. Plant Cell Rep. 19: 257-262.

Hager M. and Bock R. 2000. Enslaved bacteria as new hope for plant biotechnologists. Appl. Microbiol. Biotechnol. 54: 302310.

Hager M., Biehler K., Illerhaus J., Ruf S. and Bock R. 1999. Targeted inactivation of the smallest plastid genome-encoded open reading frame reveals a novel and essential subunit of the cytochrome $b_{6}$ f complex. EMBO J. 18: 5834-5842.

Hajdukiewicz P.T.J., Gilbertson L. and Staub J.M. 2001. Multiple pathways for Cre/lox-mediated recombination in plastids. Plant J. 27: 161-170.

Harrier L.A. and Millam S. 2001. Biolistic transformation of arbuscular mycorrhizal fungi: progress and perspectives. Mol. Biotechnol. 18: 25-33.

Havey M.J., Lilly J.W., Bohanec B., Bartoszewski G. and Malepszy S. 2002. Cucumber: a model angiosperm for mitochondrial transformation? J. Appl. Genet. 43: 1-17.

Hazell B.W., Te'o V.S.J., Bradner J.R., Bergquist P.L. and Nevalainen K.M.H. 2000. Rapid transformation of high cellulase-producing mutant strains of Trichoderma reesei by microprojectile bombardment. Lett. Appl. Microbiol. 30: $282-286$.

Hoffmann K., Verbeek M., Romano A., Dullemans A.M., van den Heuvel J.F.J.M. and van der Wilk F. 2001. Mechanical transmission of poleroviruses. J. Virol. Methods 91: 197-201.

Hou B.K., Zhou Y.H., Wan L.H., Zhang Z.L., Shen G.F., Chen Z.H. and Hu Z.M. 2003. Chloroplast transformation in oilseed rape. Transgenic Res. 12: 111-114.

Huang J., Nandi S., Wu L., Yalda D., Bartley G., Rodriguez R.L., Lonnerdal B. and Huang N. 2002. Expression of natural antimicrobial human lysozyme in rice grains. Mol. Breeding 10: 83-94.

Huang N. 2004. High-level protein expression system uses selfpollinating crops as host. BioProcess Int. 2: 54-59.

Hwang Y.-S., McCullar C. and Huang N. 2001. Evaluation of expression cassettes in developing rice endosperm using a transient expression assay. Plant Sci. 161: 1107-1116.

Hwang Y.-S., Yalda D., McCullar C., Wu L., Chen L., Pham P., Nandi S. and Huang N. 2002. Analysis of the rice endosperm-specific globulin promoter in transformed rice cells. Plant Cell Rep. 20: 842-847.

Iamtham S. and Day A. 2000. Removal of antibiotic resistance genes from transgenic tobacco plastids. Nature Biotechnol. 18: $1172-1176$.

Jackson S.A., Zhang P., Chen W.P., Phillips R.L., Friebe B., Muthukrishnan S. and Gill B.S. 2001. High-resolution structural analysis of biolistic transgene integration into the genome of wheat. Theor. Appl. Genet. 103: 56-62.
James C. 2003. Preview: Global Status of Commercialized Transgenic Crops: 2003. ISAAA Briefs No. 30. ISAAA, Ithaca, NY.

Johnston S.A., Anziano P.Q., Shark K., Sanford J.C. and Butow R.A. 1988. Mitochondrial transformation in yeast by bombardment with microprojectiles. Science 240: 1538-1541.

Kavanagh T.A., O'Driscoll K.M., McCabe P.F. and Dix P.J. 1994. Mutations conferring lincomycin, spectinomycin, and streptomycin resistance in Solanum nigrum are located in three different chloroplast genes. Mol. Gen. Genet. 242: 675680 .

Kavanagh T.A., Thanh N.D., Lao N.T., McGrath N., Peter S.O., Horvath E.M., Dix P.J. and Medgyesy P. 1999. Homeologous plastid DNA transformation in tobacco is mediated by multiple recombination events. Genetics 152: 1111-1122.

Khan M.S. and Maliga P. 1999. Fluorescent antibiotic resistance marker for tracking plastid transformation in higher plants. Nature Biotechnol. 17: 910-915.

Kim S.R., Lee J., Jun S.H., Park S., Kang H.G., Kwon S. and An G. 2003. Transgene structures in T-DNA-inserted rice plants. Plant Mol. Biol. 52: 761-773.

Klaus S.M.J., Huang F.-C., Golds T.J. and Koop H.-U. 2004. Generation of marker-free plastid transformants using a transiently cointegrated selection gene. Nature Biotechnol. 22: 225-229.

Klein T.M., Wolf E.D. and Sanford J.C. 1987. High-velocity microprojectiles for delivering nucleic acids into living cells. Nature 327: 70-73.

Kohli A., Gahakwa D., Vain P., Laurie D.A. and Christou P. 1999a. Transgene expression in rice engineered through particle bombardment: molecular factors controlling stable expression and transgene silencing. Planta 208: 88-97.

Kohli A., Griffiths S., Palacios N., Twyman R.M., Vain P., Laurie D.A. and Christou P. 1999b. Molecular characterization of transforming plasmid rearrangements in transgenic rice reveals a recombination hotspot in the CaMV $35 \mathrm{~S}$ promoter and confirms the predominance of microhomology mediated recombination. Plant J. 17: 591-601.

Kohli A., Leech M., Vain P., Laurie D.A. and Christou P. 1998. Transgene organization in rice engineered through direct DNA transfer supports a two-phase integration mechanism mediated by the establishment of integration hot spots Proc. Natl. Acad. Sci. USA 95: 7203-7208.

Kohli A., Prynne M.Q., Berta M., Pereira A., Cappell T., Twyman R.M. and Christou P. 2004. Dedifferentiationmediated changes in transposition behavior make the Activator transposon an ideal tool for functional genomics in rice. Mol. Breeding 13: 177-191.

Kohli A., Twyman R.M., Abranches A., Wegel E., Christou P. and Stoger E. 2003. Transgene integration, organization and interaction in plants. Plant Mol. Biol. 52: 247-258.

Kohli A., Xiong J., Greco R., Christou P. and Pereira A. 2001. Transcriptome Display (TTD) in indica rice using $A c$ transposition. Mol. Genet. Genom. 266: 1-11.

Kononov M.E., Bassuner B. and Gelvin S.B. 1997. Integration of T-DNA binary vector 'backbone' sequences into the tobacco genome: evidence for multiple complex patterns of integration. Plant J. 11: 945-957.

Kota M., Daniell H., Varma S., Garczynski S.F., Gould F. and William M. J. 1999. Overexpression of the Bacillus 
thuringiensis (Bt) Cry2Aa2 protein in chloroplasts confers resistance to plants against susceptible and Bt-resistant insects. Proc. Natl. Acad. Sci. USA 96: 1840-1845.

Kumar S. and Daniell H. 2004. Engineering the chloroplast genome for hyper-expression of human therapeutic proteins and vaccine antigens. Methods Mol. Biol. 267: 365-383.

Kumar S., Dhingra A. and Daniell H. 2004a. Stable transformation of the cotton plastid genome and maternal inheritence of transgenes.. Plant Mol. Biol. 56: 203-216.

Kumar S., Dhingra A. and Daniell H. 2004b. Plastid expressed betaine aldehyde dehydrogenase gene in carrot cultured cells, roots and leaves confers enhanced salt tolerance. Plant Physiol. 136: 2843-2854.

Lee S.B., Kwon H.B., Kwon S.J., Park S.C., Jeong M.J., Han S. and Daniell H. 2003. Accumulation of trehalose within transgenic chloroplasts confers drought tolerance. Mol. Breeding 11: 1-13.

Leelavathi S. and Reddy V. S. 2003. Chloroplast expression of His-tagged GUS-fusions: a general strategy to overproduce and purify foreign proteins using transplastomic plants as bioreactors. Mol. Breeding 11: 49-58.

Lepri O., Bassie L., Safwat G., Thu-Hang P., Trung-Nghia P., Höltta E., Christou P. and Capell T. 2001. Over-expression of the human ornithine decarboxylase cDNA in transgenic rice plants alters the polyamine pools in a tissue-specific manner. Mol. Genet. Genom. 266: 303-312.

Lepri O., Bassie L., Thu-Hang P., Christou P. and Capell T. 2002. Endogenous enzyme activities and polyamine levels in diverse rice cultivars depend on the genetic background and are not affected by the presence of the hygromycin phosphotransferase selectable marker. Theor. Appl. Genet. 105: 594-603.

Loc N.T., Tinjuangjun P., Gatehouse A.M.R., Christou P. and Gatehouse J.A. 2002. Linear transgene constructs lacking vector backbone sequences generate transgenic rice plants which accumulate higher levels of proteins conferring insect resistance. Mol. Breeding 9: 231-244.

Ma J.K.-C., Lehner T., Stabila P., Fux C.I. and Hiatt A. 1994. Assembly of monoclonal antibodies with $\mathrm{IgGl}$ and $\mathrm{IgA}$ heavy-chain domains in transgenic tobacco plants. Eur. J. Immunol. 24: 131-138.

Makarevitch I., Svitashev S.K. and Somers D.A. 2003. Complete sequence analysis of transgene loci from plants transformed via microprojectile bombardment. Plant Mol. Biol. 52: $421-432$

Maliga P. 2004. Plastid transformation in higher plants. Annu. Rev. Plant Biol. 55: 289-313.

Maqbool S.B., Riazuddin S., Loc N.T., Gatehouse A.M.R., Gatehouse J.A. and Christou P. 2001. Expression of multiple insecticidal genes confers broad resistance against a range of different rice pests. Mol. Breeding 7: 85-93.

McBride K.E., Svab Z., Schaaf D.J., Hogan P.S., Stalker D.M. and Maliga P. 1995. Amplification of a chimeric Bacillus gene in chloroplasts leads to an extraordinary level of an insecticidal protein in tobacco. Bio/Technology 13: 362-365.

McCormac A.C., Fowler M.R., Chen D.F. and Elliott M.C. 2001. Efficient co-transformation of Nicotiana tabacum by two independent T-DNAs, the effect of T-DNA size and implications for genetic separation. Transgenic Res. 10: $143-155$.
Mehlo L., Mazithulela G., Twyman R.M., Boulton M.I., Davies J.W. and Christou P. 2000. Structural analysis of transgene rearrangements and effects on expression in transgenic maize plants generated by particle bombardment. Maydica 45: 277-287.

Molina A., Herva-Stubbs S., Daniell H., Mingo-Castel A.M. and Veramendi J. 2004. High yield expression of a viral peptide animal vaccine in transgenic tobacco chloroplasts. Plant Biotechnol. J. 2: 141-153.

Mullen J., Adam G., Blowers A. and Farle E. 1998. Biolistic transfer of large DNA fragments to tobacco cells using YACs retrofitted for plant transformation. Mol. Breeding 4: 449457.

Nandi S., Suzuki A., Huang J., Yalda D., Pham P., Wu L., Bartley G., Huang N. and Lonnerdal B. 2002. Expression of human lactoferrin in transgenic rice grains for the application in infant formula. Plant Sci. 163: 713-722.

Narayanan N.N., Baisakh N., Oliva N.P., Vera Cruz C.M., Gnanamanickam S.S., Datta K. and Datta S.K. 2004. Molecular breeding: marker-assisted selection combined with biolistic transformation for blast and bacterial blight resistance in Indica rice (cv. CO39). Mol. Breeding 14: 61-71.

Narayanan N.N., Baisakh N., Vera Cruz C.M., Gnanamanickam S.S., Datta K. and Datta S.K. 2002. Molecular breeding for the development of blast and bacterial blight resistance in rice cv. IR50. Crop Sci. 42: 2072-2079.

Negrutiu I., Shillito R.D., Potrykus I., Biasini G. and Sala F. 1987. Hybrid genes in the analysis of transformation conditions. I. Setting up a simple method for direct gene transfer in plant protoplasts. Plant Mol. Biol. 8: 363-373.

Nicholson L., Gonzalez-Melendi P., van Dolleweerd C., Tuck H., Perrin Y., Ma J.K.-C., Fischer R., Christou P. and Stoger E. 2005. A recombinant multimeric immunoglobulin expressed in rice shows assembly dependent subcellular localization in endosperm cells. Plant Biotechnol. 3: 115-127.

Noury M., Bassie L., Lepri O., Kurek I., Christou P. and Capell T. 2000. A transgenic cell lineage expressing the oat arginine decarboxylase $(a d c)$ cDNA constitutively accumulates putrescine in callus and seeds but not in vegetative tissues. Plant Mol. Biol. 43: 537-544.

O'Kennedy K., Burger J. and Berger D. 2001. Transformation of elite white maize using the particle inflow gun and detailed analysis of low-copy integration event. Plant Cell Rep. 20: 721-730.

O'Neill C., Horvath G.V., Horvath E., Dix P.J. and Medgyesy P. 1993. Chloroplast transformation in plants: polyethylene glycol (PEG) treatment of protoplasts is an alternative to biolistic delivery systems. Plant J. 3: 729-738.

Pawlowski W.P. and Somers D.A. 1998. Transgenic DNA integrated into the oat genome is frequently interspersed by host DNA. Proc. Natl. Acad. Sci USA 95: 12106-12110.

Permingeat H.R., Alvarez M.L., Cervigni G.D.L., Ravizzini R.A. and Vallejas R.H. 2003. Stable wheat transformation obtained without selectable markers. Plant Mol. Biol. 52: 415-419.

Popelka J.C. and Altpeter F. 2003a. Agrobacterium tumefaciens-mediated genetic transformation of rye (Secale cereale L.). Mol. Breeding 11: 203-211.

Popelka J.C. and Altpeter F. 2003b. Evaluation of rye (Secale cereale $\mathrm{L}$ ) inbred lines and their crosses for tissue culture 
response and stable genetic transformation of homozygous rye inbred line L22 by biolistic gene transfer. Theor. Appl. Genet. 107: 583-590.

Popelka J.C., Xu J. and Altpeter F. 2003. Generation of rye plants with low copy number after biolistic gene transfer and production of instantly marker-free transgenic rye. Transgenic Res. 12: 587-596.

Ramanathan V. and Veluthambi K. 1995. Transfer of nonT-DNA portions of the Agrobacterium tumefaciens Ti plasmid pTiA6 from the left terminus of TL-DNA. Plant Mol. Biol. 28: 1149-1154.

Randolph-Anderson B.L., Boynton J.E., Gillham N.W., Harris E.H., Johnson A.M., Dorthu M.-P. and Matagne R.F. 1993. Further characterization of the respiratory deficient dum-1 mutation of Chlamydomonas reinhardtii and its use as a recipient for mitochondrial transformation. Mol. Gen. Genet. 236: 235-244.

Reddy P.M., Ladha J.K., Ramos M.C., Maillet F., Hernandez R.J., Torrizo L.B., Oliva N.P., Datta S.K. and Datta K. 1998. Rhizobial lipochitooligosaccharide nodulation factors activate expression of the legume early nodulin gene ENOD12 in rice. Plant J. 14: 693-702.

Romano A., van der Plas L.H.W., Witholt B., Eggink G. and Mooibroek H. 2005. Expression of poly-3-(R)-hydroxyalkanoate (PHA) polymerase and acyl-CoA-transacylase in plastids of transgenic potato leads to the synthesis of a hydrophobic polymer, presumably medium-chain-length PHAs. Planta 220: 45-464.

Romano A., Raemakers K., Visser R. and Mooibroek H. 2001. Transformation of potato (Solanum tuberosum) using particle bombardment. Plant Cell Rep. 20: 198-204.

Romano A., Raemakers K., Bernardi J., Visser R. and Mooibroek H. 2003a. Transgene organization in potato after particle bombardment-mediated (co)transformation using plasmids and gene cassettes. Transgenic Res. 12: $461-473$.

Romano A., Vincken J.-P., Raemakers K., Mooibroek H. and Visser R. 2003b. Potato genetic transformation and its application in polymer modification. In: Singh R. and Jaiwal P. (eds), Plant Genetic Engineering. (Vol. 3.). Sci-Tech Publishing Company, Houston, USA, pp. 55-91.

Ruf S., Hermann M., Berger I.J., Carrer H. and Bock R. 2001. Stable genetic transformation of tomato plastids and expression of a foreign protein in fruit. Nature Biotechnol. 19: $870-875$.

Ruf S., Kössel H. and Bock R. 1997. Targeted inactivation of a tobacco intron-containing open reading frame reveals a novel chloroplast-encoded photosystem I-related gene. J. Cell Biol. 139: 95-102.

Ruiz G. 2002. Optimization of codon composition and regulatory elements for expression of the human IGF-1 in transgenic chloroplasts. M.S. thesis, University of Central Florida, Orlando, FL.

Ruiz O.N., Hussein H., Terry N. and Daniell H. 2003. Phytoremediation of organomercurial compounds via chloroplast genetic engineering. Plant Physiol. 132: 1344-1352.

Sanchirico M.E., Fox T.D. and Mason T.L. 1998. Accumulation of mitochondrially synthesized Saccharomyces cerevisiae Cox $2 p$ and Cox $3 p$ depends on targeting information in untranslated portions of their mRNAs. EMBO J. 17: 57965804.
Sawasaki T., Takahashi M., Goshima N. and Morikawa H. 1998. Structures of transgene loci in transgenic Arabidopsis plants obtained by particle bombardment: junction regions can bind to nuclear matrices. Gene 218: 27-35.

Shillito R.D., Saul M.W., Paszkowski J., Muller M. and Potrykus I. 1985. High efficiency direct gene transfer to plants. Bio/Technology 3: 1099-1103.

Shibata D. and Liu Y.G. 2000. Agrobacterium-mediated plant transformation with large DNA fragments. Trends Plant Sci. 5: 354-357.

Sidorov V.A., Kasten D., Pang S.Z., Hajdukiewicz P.T., Staub J.M. and Nehra N.S. 1999. Stable chloroplast transformation in potato: use of green fluorescent protein as a plastid marker. Plant J. 19: 209-216.

Singleton M.L. 2003. Expression of CaF1 and LcrV as a fusion protein for a vaccine against Yersinia pestis via chloroplast genetic engineering. M.S. thesis, University of Central Florida, Orlando, FL.

Sivamani E., Huet H., Shen P., Ong C.A., DeKochko A., Fauquet C.M. and Beachy R.N. 1999. Rice plants (Oryza sativa $\mathrm{L}$.) containing three rice tungro spherical virus (RTSV) coat protein transgenes are resistant to virus infection. Mol. Breeding 5: 177-185.

Skarjinskaia M., Svab Z. and Maliga P. 2003. Plastid transformation in Lesquerella fendleri, an oilseed Brassicacea. Transgenic Res. 12: 115-122.

Smith N., Kilpatrick J.G. and Whitelam G.C. 2001. Superfluous transgene integration in plants. Crit. Rev. Plant Sci. 20: 215-249.

Staub J.M., Garcia B., Graves J., Hajdukiewicz P.T.J., Hunter P., Nehra N., Paradkar V., Schlittler M., Carroll J.A., Spatola L., Ward D., Ye G.N. and Russell D.A. 2000. Highyield production of a human therapeutic protein in tobacco chloroplasts. Nature Biotechnol. 18: 333-338.

Steele D.F., Butler C.A. and Fox T.D. 1996. Expression of a recoded nuclear gene inserted into yeast mitochondrial DNA is limited by mRNA-specific translational activation. Proc. Natl. Acad. Sci. USA 93: 5253-5257.

Stoger E., Williams S., Keen D. and Christou P. 1998. Molecular characteristics of transgenic wheat and the effect on transgene expression. Transgenic Res. 7: 463-471.

Sunagawa M. and Magae Y. 2002. Transformation of the edible mushroom Pleurotus ostreatus by particle bombardment. FEMS Microbiol. Lett. 211: 143-146.

Svab Z., Hajdukiewicz P. and Maliga P. 1990. Stable transformation of plastids in higher plants. Proc. Natl. Acad. Sci. USA 87: 8526-8530.

Svab Z. and Maliga P. 1993. High-frequency plastid transformation in tobacco by selection for a chimeric aadA gene. Proc. Natl. Acad. Sci. USA 90: 913-917.

Svitashev S., Ananiev E., Pawlowski W.P. and Somers D.A. 2000. Association of transgene integration sites with chromosome rearrangements in hexaploid oat. Theor. Appl. Genet. 100: 872-880.

Svitashev S.K., Pawlowski W.P., Makarevitch I., Plank D.W. and Somers D.A. 2002. Complex transgene locus structures implicate multiple mechanisms for plant transgene rearrangement. Plant J. 32: 433-445.

Svitashev S. and Somers D.A. 2001. Genomic interspersions determine the size and complexity of transgene loci in transgenic plants produced by microprojectile bombardment. Genome 44: 691-697. 
Taylor N.J. and Fauquet C.M. 2002. Microparticle bombardment as a tool in plant science and agricultural biotechnology. DNA Cell Biol. 21: 963-977.

Thu-Hang P., Sawfat G., Bassie L., Trung-Ngia P., Christou P. and Capell T. 2002. Expression of a heterologous S-adenosylmethyonine decarboxylase cDNA in plants demonstrates that changes in SAMDC activity determine levels of the higher polyamines spermidine and spermine. Plant Physiol. 129: $1744-1754$

Torres M. 2001. Expression of interferon alpha 5 in transgenic tobacco chloroplasts. M.S. thesis, University of Central Florida, Orlando, USA.

Tregoning J.S., Nixon P., Kuroda H., Svab Z., Clare S. and Bowe F. et al. 2003. Expression of tetanus toxin fragment $\mathrm{C}$ in tobacco chloroplasts. Nucleic Acids Res. 31: 11741179.

Trung-Nghia P., Bassie L., Safwat G., Lepri O., Thu-Hang P., Rocha P., Christou P. and Capell T. 2003. Reduction in the endogenous arginine decarboxylase transcript levels in rice leads to depletion of the putrescine and spermidine pools with no concomitant changes in the expression of downstream genes in the polyamine biosynthetic pathway. Planta 218: 125-134.

Tu J., Datta K., Alam M.F., Khush G.S. and Datta S.K. 1998a. Expression and function of a hybrid Bt toxin gene in transgenic rice conferring resistance to insect pests. Plant Biotechnol. (Jap.) 15: 183-191.

Tu J., Ona I., Zhang Q., Mew T.W., Khush G.S. and Datta S.K. 1998b. Transgenic rice variety IR72 with $\mathrm{Xa21}$ is resistant to bacterial blight. Theor. Appl. Genet. 97: 31-36.

Tu J., Datta K., Khush G.S., Zhang Q. and Datta S.K. 2000a. Field performance of Xa21 transgenic indica rice (Oryza sativa L.) IR72. Theor. Appl. Genet. 101: 15-20.

Tu J., Zhang G., Datta K., Xu C., He Y., Zhang Q., Khush G.S. and Datta S.K. 2000b. Field performance of transgenic elite commercial hybrid rice expressing Bacillus thuringiensis d-endotoxin. Nature Biotechnol. 18: 1101-1104.

Tu J., Datta K., Oliva N., Zhang G., Xu C., Khush G.S., Zhang Q. and Datta S.K. 2003. Site-independently integrated transgenes in the elite restorer rice line Minghui 63 allow removal of a selectable marker from the gene of interest by self-segregation. Plant Biotechnol. J. 1: 155-165.

Twyman R.M., Stoger E., Kohli A. and Christou P. 2002. Foreign DNA: integration and expression in transgenic plants. In: Setlow JK (ed.), Genetic Engineering: Principles and Practice, Vol. 24. Kluwer Academic/Plenum Publishers, NY, pp. 107-136.

Twyman R.M., Stoger E., Schillberg S., Christou P. and Fischer R. 2003. Molecular farming in plants: host systems and expression technology. Trends Biotechnol. 21: 570-578.

Tzfira T. and Citovsky V. 2003. The Agrobacterium-plant cell interaction. Taking biology lessons from a bug. Plant Physiol. 133: 943-947.
Valentine L. 2003. Agrobacterium tumefaciens and the plant: the David and Goliath of modern genetics. Plant Physiol. 133: 948-955.

Van der Graaff E., den Dulk-Ras A. and Hooykaas P.J. 1996. Deviating T-DNA transfer from Agrobacterium tumefaciens to plants. Plant Mol. Biol. 31: 677-681.

Vaneck J.M., Blowers A.D. and Earle E.D. 1995. Stable transformation of tomato cell-cultures after bombardment with plasmid and YAC DNA. Plant Cell Rep. 14: 299-304.

Varshney A. and Altpeter F. 2001. Stable transformation and tissue culture response in current European winter wheat (Triticum aestivum L.) germplasm. Mol. Breeding 8: 295-309.

Vasconcelos M., Datta K., Oliva N., Khalekuzzaman M., Torrizo L., Krishnan S., Oliveira M., Goto F. and Datta S.K. 2003. Enhanced iron and zinc accumulation in trangenic rice with the ferritin gene. Plant Sci. 64: 371-378.

Vasil I.K., Bean S., Zhao J.M., McCluskey P., Lookhart G., Zhao H.P., Altpeter F. and Vasil V. 2001. Evaluation of baking properties and gluten protein composition of field grown transgenic wheat lines expressing high molecular weight glutenin gene $1 A x 1$. J. Plant Physiol. 158: 521-528.

Viitanen P.V., Devine A.L., Khan M.S., Deuel D.L., VanDyk D.E. and Daniell H. 2004. Metabolic engineering of the chloroplast genome using the $E$. coli $u b i \mathrm{C}$ gene reveals that chorismate is a readily abundant plant precursor for $p$-hydroxybenzoic acid biosynthesis. Plant Physiol. 136: 40484060.

Watson J., Koya V., Leppla S.H. and Daniell H. 2004. Expression of Bacillus anthracis protective antigen in transgenic chloroplasts of tobacco, a non-food/feed crop. Vaccine 22: 4374-4384.

Verhoog H. 2003. Naturalness and the genetic modification of animals. Trends Biotechnol. 21: 294-297.

Wenck A., Czako M., Kanevski I. and Marton L. 1997. Frequent collinear long transfer of DNA inclusive of the whole binary vector during Agrobacterium-mediated transformation. Plant Mol. Biol. 34: 913-922.

Wu L., Nandi S., Chen L., Rodriguez R.L. and Huang N. 2002. Expression and inheritance of nine transgenes in rice. Transgenic Res. 11: 533-541.

Yang D., Wu L., Hwang Y.S., Chen L. and Huang N. 2001. Expression of the REB transcriptional activator in rice grains improves the yield of recombinant proteins whose genes are controlled by a Reb-responsive promoter. Proc. Natl. Acad. Sci. USA 98: 11438-11443.

Ye G., Tu J., Hu C., Datta K. and Datta S.K. 2001. Transgenic IR72 with fused Bt gene crylAB/crylAc from Bacillus thuringiensis is resistant against four lepidopteran species under field conditions. Plant Biotechnol. 18: 125-133.

Zhang S., Gu J., Yang N.S., Kao C., Gardner T.A., Eble J.N. and Cheng L. 2002. Relative promoter strengths in four human prostate cancer cell lines evaluated by particle bombardment-mediated gene transfer. Prostate 51: 286-292. 
Copyright of Molecular Breeding is the property of Springer Science \& Business Media B.V.. The copyright in an individual article may be maintained by the author in certain cases. Content may not be copied or emailed to multiple sites or posted to a listserv without the copyright holder's express written permission. However, users may print, download, or email articles for individual use. 